\title{
7 Union formation and partner choice
}

\author{
Christelle Hamel, Doreen Huschek, \\ Nadja Milewski and Helga de Valk
}

\subsection{Introduction}

Partner choice and union formation are important events in the lives of young adults. The specific choices involved in these events are determined by a range of factors. For example, research indicates that social homogamy plays an important role in partner choice. The timing of union formation is, moreover, strongly correlated with people's educational level and other social background characteristics. At the same time, common social patterns in partner selection and union formation do change over time and in the succession of generations. Two of the most significant changes to occur across Europe in recent decades are a considerable postponement of entry into union and parenthood and the marked decline of formal marriage. On one hand, these changes are linked to rising numbers of people in pursuit of higher education, thus leading to an older average age for completion of the educational career. On the other hand, there has been a widely acknowledged transformation of norms and values vis-à-vis sexuality and marriage. Though such trends vary by country (Sobotka \& Toulemon 2008), they are quite well documented for Europe. The transformation first gained visibility in Sweden during the late 1960s, having gradually spread to Western Europe, Southern Europe (Prioux 2006) and, more recently, Eastern Europe (Atkinson \& Marlier 2010). Prior research reveals gender differences in union formation behaviour, pointing out how women start unions earlier than men and choose partners who are, on the whole, slightly older than themselves (Kalmijn 2007; Liefbroer \& Goldscheider 2006).

Unlike our knowledge about general trends in the European population, data concerning partner choice and union formation patterns among young adults of immigrant origin in Europe is limited. And that is despite - if not a very impetus for - widespread 'folk' ideas about immigrants, for example, their large, overly-populating families, their 'conservative' family values and their rules for partner choice, specifically for young women. The children of immigrants - a generation born and raised in Europe - find 
themselves in a clearly different set of circumstances than their parents. These mothers and fathers comprising the first generation came as married couples or by large majority chose a partner from their country of origin upon founding a family. By contrast, the second generation's link with their parents' country of origin is not mediated by the personal experience of migration. Yet at the same time, these young adults find themselves in a position distinct from their peers with native-born parents. That is, the second generation's 'marriage market' also includes their parents' country of origin. Links created through regular visitations (for example, on holidays or for family gatherings), create opportunities for them to find potential partners there. Having two country contexts in which to find a partner also ushers in different sets - two at least - of norms, values and practices.

In many societies, union formation choices and related attitudes towards family are among the core values (Lesthaeghe 2000) transferred from parent to child (De Valk \& Liefbroer 2007). Marriage among children raised in the country of immigration thus often becomes a particularly crucial issue in immigrant families, with the second generation being required to negotiate differences between their parents' cultural preferences and their own. Union formation patterns in Turkey and Morocco are markedly different from those in Europe in several respects. Marriage is practically universal in Turkey and Morocco. While marrying age remains low in Turkey (HUIPS 2004: 91), Morocco's has risen sharply in recent decades (Ouadah-Bedidi \& Vallin 2000). The situation in former Yugoslavian countries differs less from that in North-Western Europe. Communism's collapse and the fall of the Iron Curtain in the late 1980s and early 1990s dramatically affected family life in Central and Eastern Europe. For one, it led to the lowest fertility rates in Europe. The economic crisis following the political developments, together with the end of family support policies and changes in family values, resulted in a dramatic decline in marriage and childbearing within marriage as well as a substantial increase in unmarried cohabitation and extramarital childbearing (Philipov \& Dorbritz 2003). An interesting question for us to consider now thus concerns the union and family formation behaviour of the second generations of immigrant origin in Western Europe. How and to what degree are they reflections of their parents' countries of origin versus their own countries of birth? How do they represent the two respective cultures? And how do they mirror or deviate from actual circumstances in the 'motherland'?

Most available studies on children of immigrants do not allow us to distinguish between first and second generations, nor do they have a comparative focus across immigration countries or origin groups. The present chapter aims, therefore, to fill part of this gap by analysing the Turkish, Moroccan and former Yugoslavian second generations in comparison to their peers with native-born parents. We specifically focus on the transition to first union: its timing, the prevalence of different types of union 
(marriage or cohabitation), the partners' origins and socio-demographic characteristics and the share of transnational or mixed unions. We endeavour to unravel how socio-economic and migration background characteristics interact with decisions by the second generation regarding union formation. How and to what extent are their union formation choices affected by structural constraints, by the local or national context in which they live and/or by individual preferences? Observed variation between countries and between cities is discussed in relation to the history of Turkish, Moroccan and former Yugoslavian migration, as well as the size of the marriage market in each country. We assess to what extent young adults of immigrant parentage follow common paths of union formation in their parents' country of origin or take other routes. We also look at the commonalities and differences between young adults of Turkish, Moroccan and former Yugoslavian descent and their peers of non-immigrant parentage in selected European cities.

\subsection{Transition to first union}

\section{Union formation in Morocco, Turkey and former Yugoslavia}

Entry into partnership is one of the key markers for the transition to adulthood. The Turkish and Moroccan and, albeit to a lesser extent, former Yugoslavian parents of respondents to the TIES survey come from places where, unlike Western countries, marriage is virtually universal and unmarried cohabitation remains rare (Locoh \& Ouadah-Bedidi 2010). In Morocco, sexual activity outside marriage is considered prostitution; unmarried cohabitation is hence illegal. Unmarried people who engage in sexual intercourse can be jailed under article 490 of the Moroccan penal code, even though the law is rarely invoked today. Despite major improvements in women's rights, recent reforms to Moroccan legislation - notably in 2004 to the personal status code, the Mudawana (see Zoglin 2009) have basically left this situation unchanged.

In Turkey, the 2001 reform of the civil code and the 2004 reform of the penal code eliminated references to patriarchal concepts such as morality, chastity and honour, as well as abolished previous practices of discrimination towards unmarried women with children. It also recognised women's autonomy over their own bodies and sexuality, though the practice of 'virginity testing' - commonly used in the 1990s by government physicians on prostitutes or women accused of extramarital sex (Parla 2001) - has not been explicitly banned in all circumstances (Anil 2005; Ilkkaracan 2007). In both countries, though especially in Morocco, practices and opinions surrounding sexuality and gender roles have changed among the younger generation; that being said, regulations regarding sexual activity remain particularly strict. 
Turkey and Morocco differ markedly when it comes to the timing of union formation. This is the case despite the countries' common heritage of a 'culture of honour and shame' (Peristiany 1965) that makes women's premarital virginity a matter of the family's reputation (Parla 2001; Ozyegin 2009) and despite the fact that marriage is practically universal. According to the 2003 Turkish Demographic and Health Survey, the median age of first-time marriage among women aged 25-29 was 21, while for women aged 45-49 it was nineteen; this indicates a two-year increase occurred over twenty years. Only 3 per cent of the women aged 40-44 never married (HUIPS 2004). The relatively young age at the first union formation correlates with low levels of educational attainment. In Morocco, by contrast, the changes began earlier and are more pronounced: first-time marriage age has risen drastically in the last decades, with an age increase of almost eight years since the 1960s (Ouadah-Bedidi \& Vallin 2000). The median age at first marriage among women aged 25-29 in 2004 was 24 (Loudghiri 2003), which is comparable to that in some European countries (Sobotka \& Toulemon 2008). Many young men and women today also remain single longer. Demographers see this as a sign that for younger generations the universality of marriage - and hence the norm of premarital virginity - are under challenge (Locoh \& Ouadah-Bedidi 2010). Because of the Moroccan law, the young generation cannot openly contest norms on marriage and virginity, but ethnographic research, especially on abortion and single motherhood, has shown that their actual hold is weakening. Still, single mothers suffer from stigmatisation and social isolation (Naamane-Guessous 1985).

Data on union formation in former Yugoslavia give an incomplete picture, as no fertility or family surveys have recently been conducted in those countries. In addition, unmarried cohabitation is not recorded in the census (Thornton \& Philipov 2009). We can only present the mean first-time marriage age in 1980 and 2000, having risen from 22.5 to 25 in Serbia and Montenegro; from 22 to 25 in Croatia; and from 22 to 23 in Bosnia and Herzegovina (between 1980 and 1990, data unavailable for 2000) (Billari 2005).

\section{Partnership experiences of the TIES respondents}

Across the board, TIES respondents are young adults who, at the time of the survey, may or may not have already entered into a partnership. In the section that follows, we define 'union' as simply the formation of a co-residential partnership, without differentiating between marriages and cohabitations. Tables $7.1 \mathrm{a}$ and $7.1 \mathrm{~b}$ provide a first descriptive overview of young adults who entered a first union.

Given that men and women from the same origin group and living in the same city are roughly the same age, our comparison by sex is relevant. 


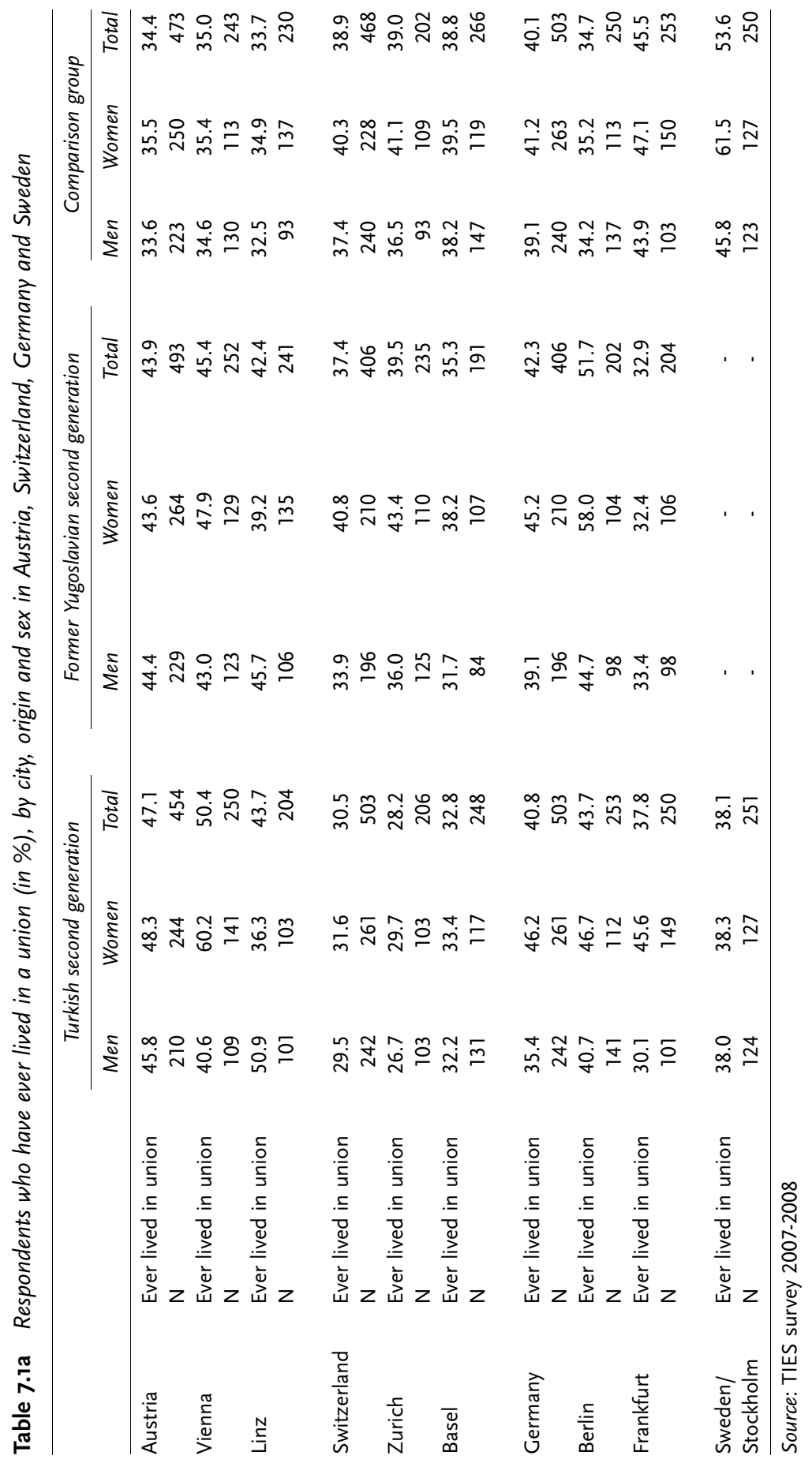




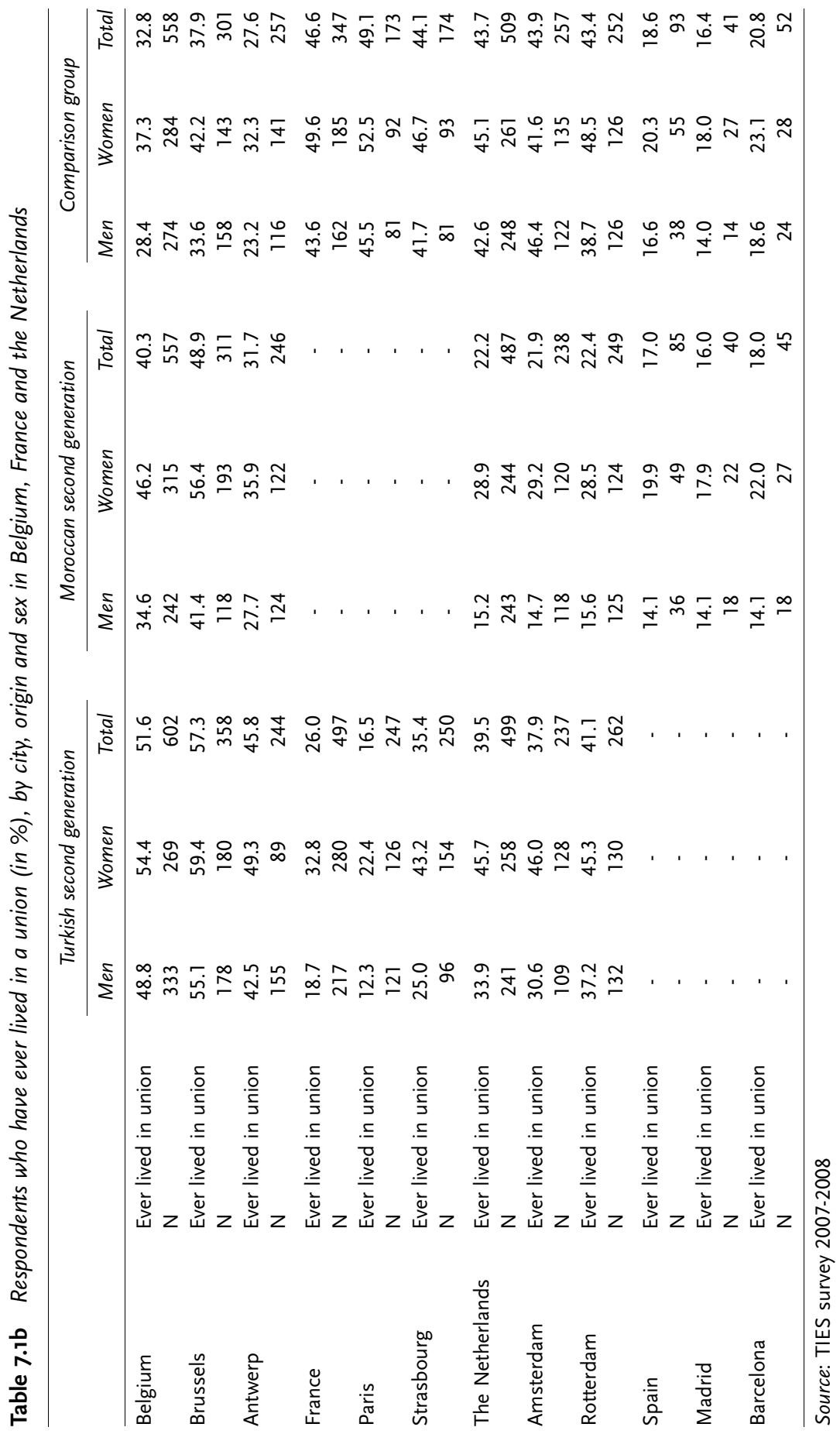


In line with previous studies, we mostly found that more women than men had already formed a first union (tables 7.1a and 7.1b). With a few exceptions, this holds true for women of all origins in our study, indicating that, regardless of people's background, there are similar gender-related mechanisms at work.

The direct comparison across groups and cities is not meaningful. This is because there are too many potential explanations for variation between cities with regard to the proportion of those who ever formed a union within each group, as well as across groups in the same city. Possible influential factors include respective social norms about 'ideal' ages and stages in a person's life for forming a union, the variation in the respondents' mean age and differences in respondents' level of education (see chapter 5). The following subsections endeavour to more specifically assess these influential factors at different levels. It is worth mentioning that the very young age structure of the Spanish sample is reflected in very low shares of persons who have ever lived in a union. For this reason, the Spanish case is excluded from the following analyses; case numbers are simply too small.

\section{Age at first union formation}

Although the descriptive findings yield some initial insights, they are limited in that they lack background information on when the young adults entered a first union. We consequently analyse the role of age in the transition to a first union by using event-history techniques and presenting the Kaplan-Meier survival estimates, which yields the estimated share of persons who enter a union and when they do so. This section analyses the role of age in the transition to a first union for men and women, respectively. A crucial indicator here is the median age at which 50 per cent of the respondents have ever had formed a union. Tables 7.2a and 7.2b give detailed information on the median ages.

Overall, we find that second-generation Turks are youngest when starting a union and the comparison group is oldest. Those of Moroccan and former Yugoslavian origin fall somewhere in between. This general pattern by origin group holds for all countries. As expected, women are generally younger upon entering their first union than men. The gender difference is, on average, 1.7 years in the comparison groups and two and three years, respectively, for second-generation Turks and Moroccans. At less than one year, the gender gap is smallest for second-generation former Yugoslavians.

To facilitate the cross-country comparison, we also analysed the findings for second-generation Turks separately by sex. Figures $7.1 \mathrm{a}$ and $7.1 \mathrm{~b}$ provide an overview by country (with two cities collapsed) of the share of men and women aged 15-30 who had not entered a first union at a given age. 


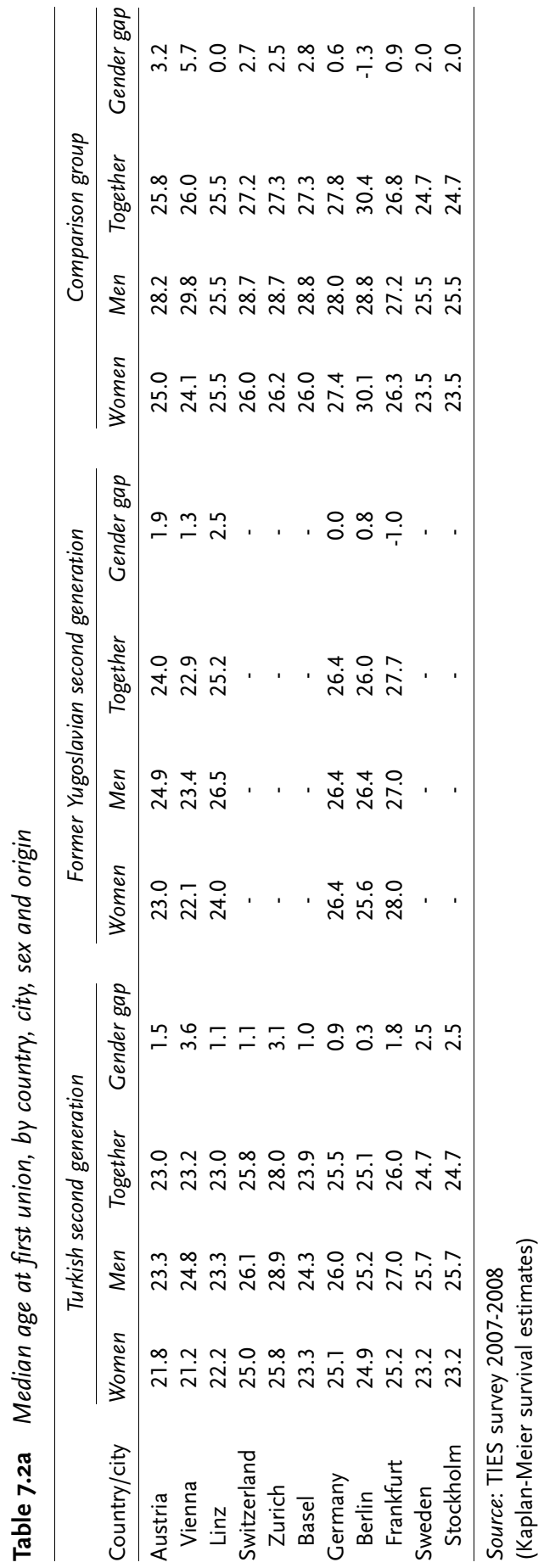




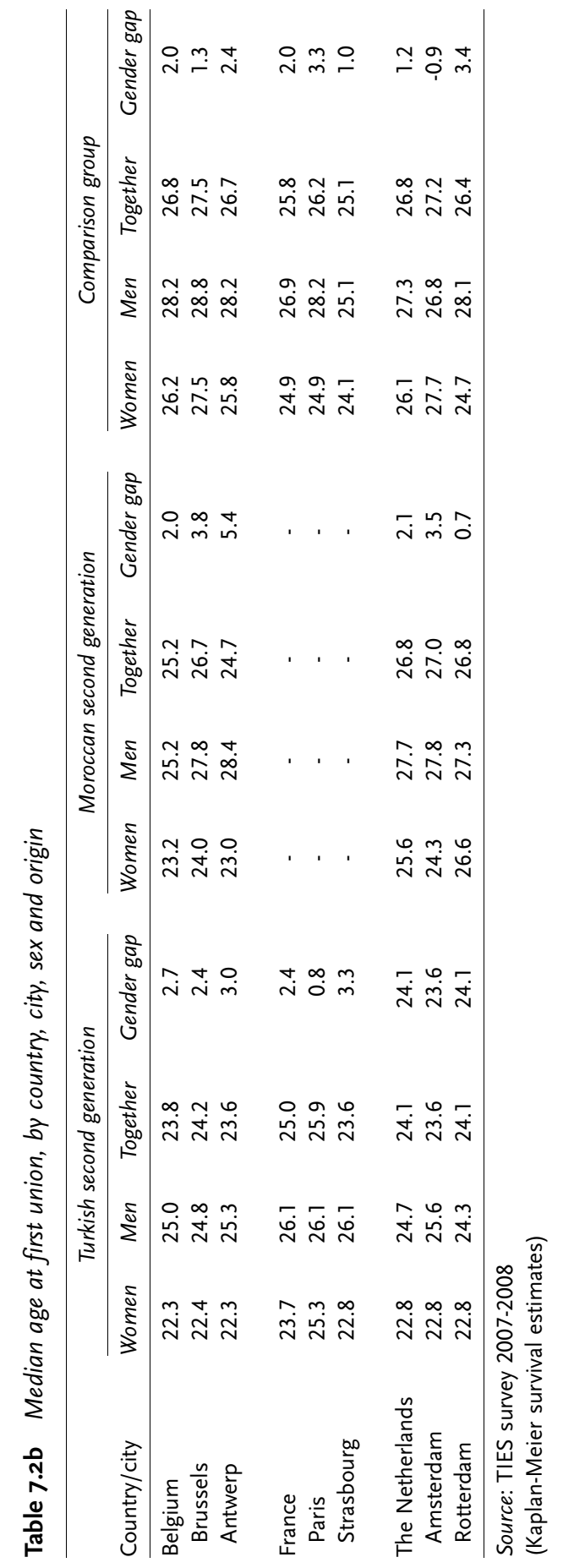


Figure 7.1a Transition to a first union of second-generation Turkish women across countries

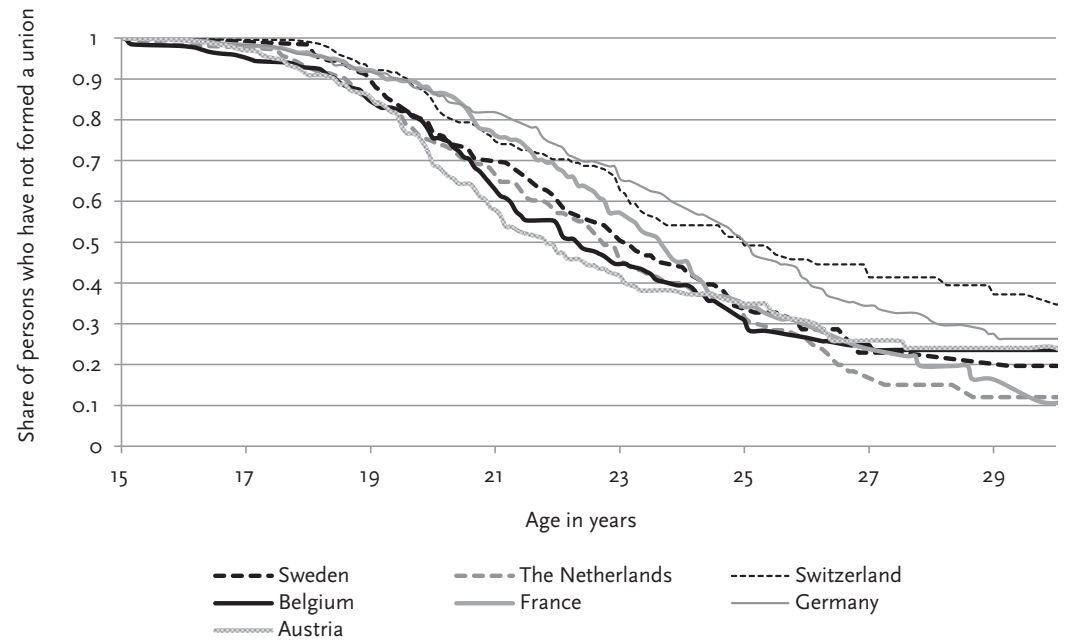

Source: TIES survey $2007-2008$

Figure 7.1b Transition to a first union of second-generation Turkish men across countries

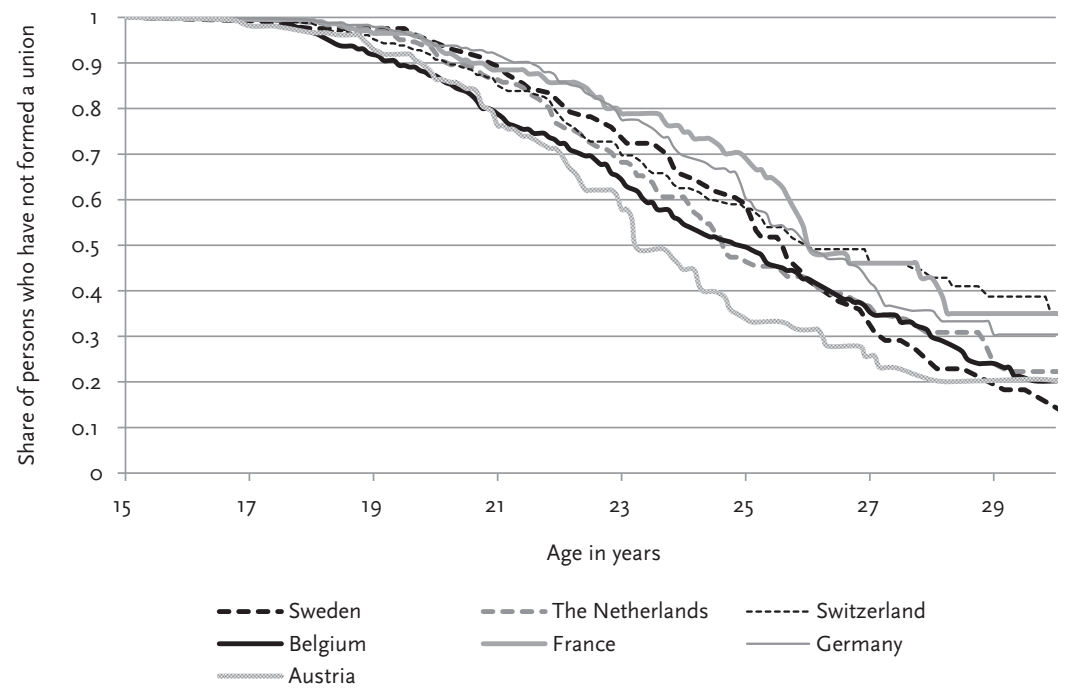

Source: TIES survey 2007-2008 
In the two Austrian cities, the formation of the first union among second-generation Turks is earliest (median age 23). The oldest union formation ages are found in Germany (25.5) and the two Swiss cities (25.8), thus revealing a difference of 2.8 years between Austria and Switzerland. If we focus solely on women, only in Austria is the age at first union comparable to that of Turkey (around 21). In all other countries, young second-generation Turkish women form a union later than the average age in Turkey.

Interestingly, as figures $7.2 \mathrm{a}$ and $7.2 \mathrm{~b}$ show, the results for the comparison groups are more heterogeneous across countries.

The cross-country comparison shows a different ranking of cities for the comparison groups. We find the lowest median age for entering a first union in Stockholm (24.7 years). As with second-generation Turks, the Swiss and German cities' comparison groups show the highest median age for the first stable union (27.2 and 27.8, respectively).

In sum, the suggestion is that national and local contexts sway union formation patterns in the Turkish second generation. This influence, however, is neither straightforward nor all-encompassing. The overall variation in timing across countries is not reflected identically among the second generations, though they do seem to follow the respective dominant pattern to a degree. In Germany and Switzerland the correlation is closer, while in Austria and Sweden, far less.

To better understand the influence of the national and city contexts on second-generation Turks, figure 7.3a compares this group with the comparison group in each country by sex. (For figures on second-generation Moroccans, see figures 7.4 in appendix; for second-generation former Yugoslavians, see figure 7.5 in appendix.)

Stockholm is a particularly interesting case for analysis here. In Sweden, as in other Scandinavian countries, young people leave the parental home earlier than in the rest of Europe (Van de Velde 2008b). This reflects the social importance attached to an individual's autonomy and independence, though is undoubtedly also facilitated by generous levels of public financial support (Van de Velde 2008a). Such subsidies allow individuals to leave the parental home even if they have not completed their education or lack permanent employment. Combined with the fact that there are few moral restrictions for unmarried couples, young adults in Sweden can move in together more easily than in countries where access to independent housing may be more complicated. It is remarkable that in Stockholm we see no difference in the median age for the transition to first union between second-generation Turks and the comparison group. We identify at least three possible explanations for this. First, the Swedish welfare state system reduces the role that different social backgrounds may have in accessing housing, thus offering opportunities that are exploited as much by second-generation Turks as the comparison group. In this sense, the Swedish welfare system produces a levelling-out effect by reducing 
Figure 7.2a Transition to a first union of comparison group women

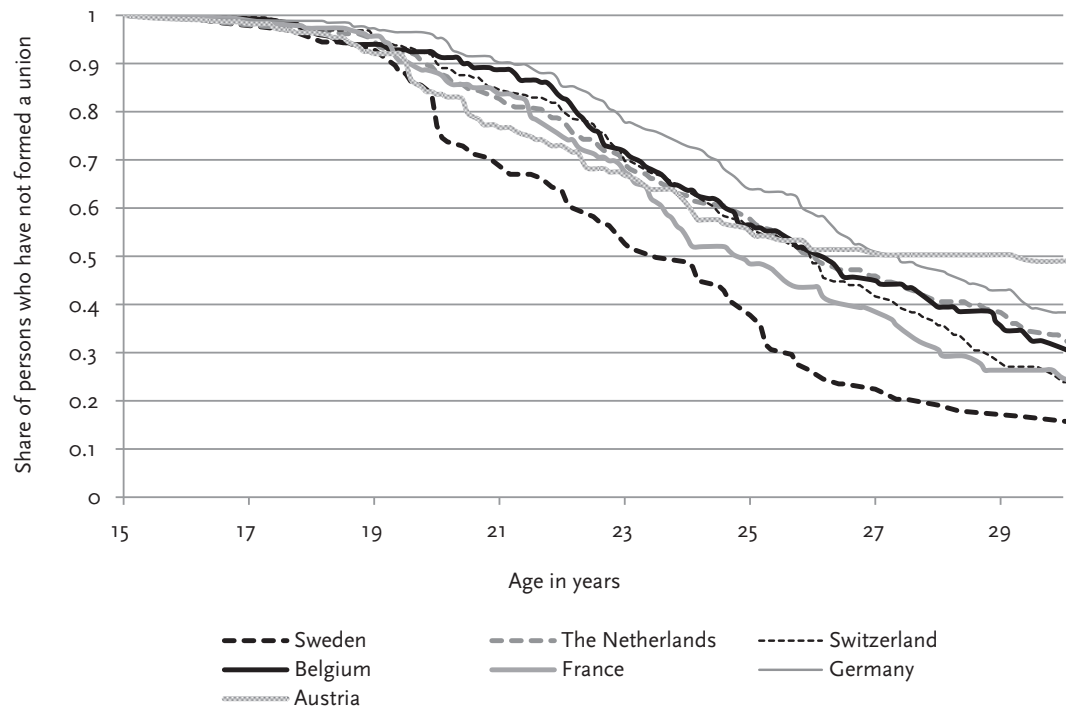

Source: TIES survey 2007-2008

Figure 7.2b Transition to a first union of comparison group men

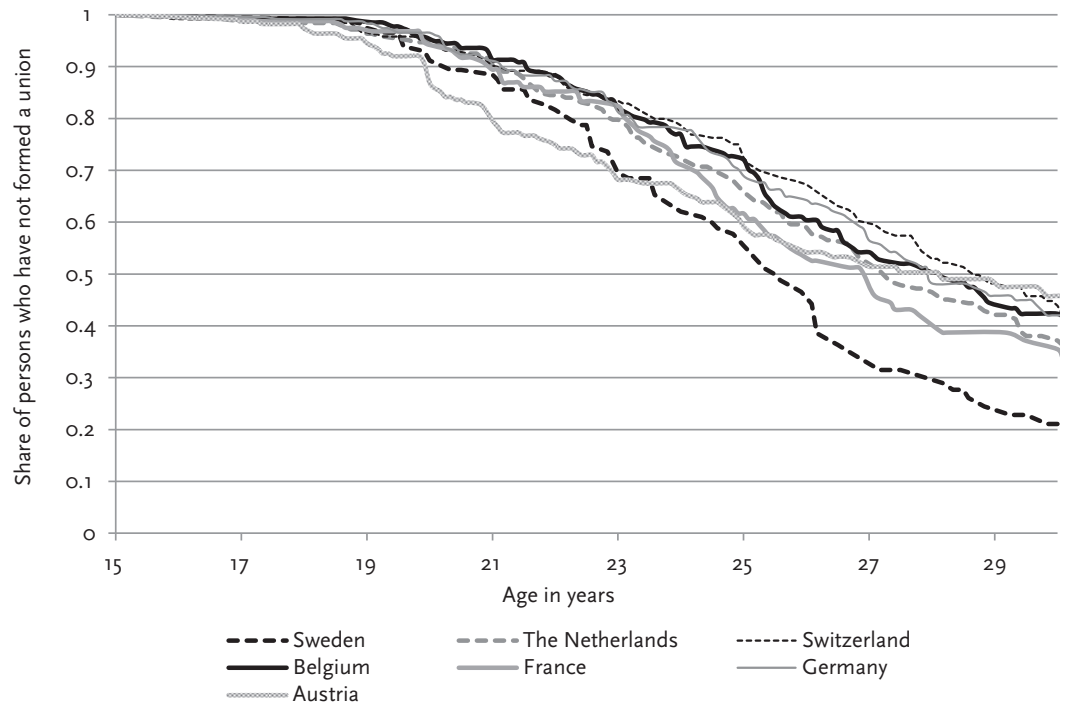

Source: TIES survey 2007-2008 
Figure 7.3a Transition to a first union in Sweden

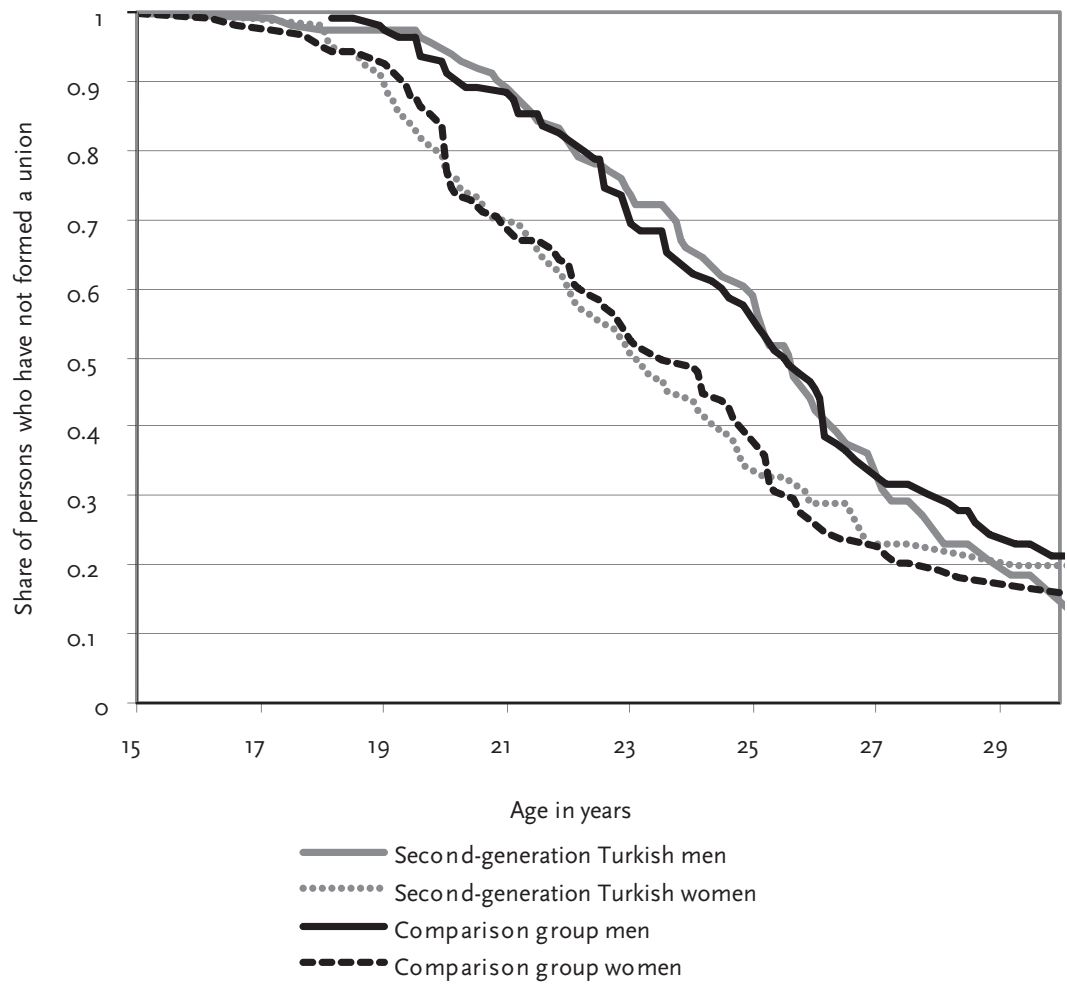

Source: TIES survey $2007-2008$

differences between poor and wealthy families across ethnic groups. A second possible explanation is that young adults of Turkish parentage follow the traditional Turkish pattern of early marriage, which is indeed facilitated by - though not contingent on - the welfare system (Bernhardt, Goldscheider, Goldscheider \& Bjeren 2007). In this respect, we therefore see that second-generation Turks in Sweden do not differ from this group as studied in other European countries. Meanwhile, such a parallel is not seen in Sweden's comparison group, who form first unions at a slightly younger age than comparison groups in other European countries, thereby increasing their union formation semblance with their Turkish peers. Yet a third possible explanation for the correspondence in median age at transition into first union between Sweden's Turkish second generation and comparison group is that at least part of this second-generation does not follow the aforementioned early marriage pattern; like comparison group couples, Turkish couples do form their own households quite young, but these are unmarried cohabitational arrangements. We expect to draw some 
conclusions concerning these explanations in section 7.3. There we examine preferred types of union (marriage or cohabitation) and opinions on female premarital sexual activity, which gives insight into whether early union formation may be associated with, or disconnected from, early marriage and notions of chastity.

Following Stockholm, the French cities have the next-youngest age for first union formation in the comparison groups (see figure 7.3b). As in Sweden, access to housing in France is available for students in higher education (Corijn 2001). This provides opportunities for young people to cohabitate. ${ }^{1}$ At the same time, France is also characterised by high levels of unemployment among young adults, which can potentially generate a postponement of first union formation. Second-generation Turkish men in the French cities show almost the same first union entrance pattern as the comparison group, though their female counterparts deviate from the main

Figure 7.3b Transition to a first union in France

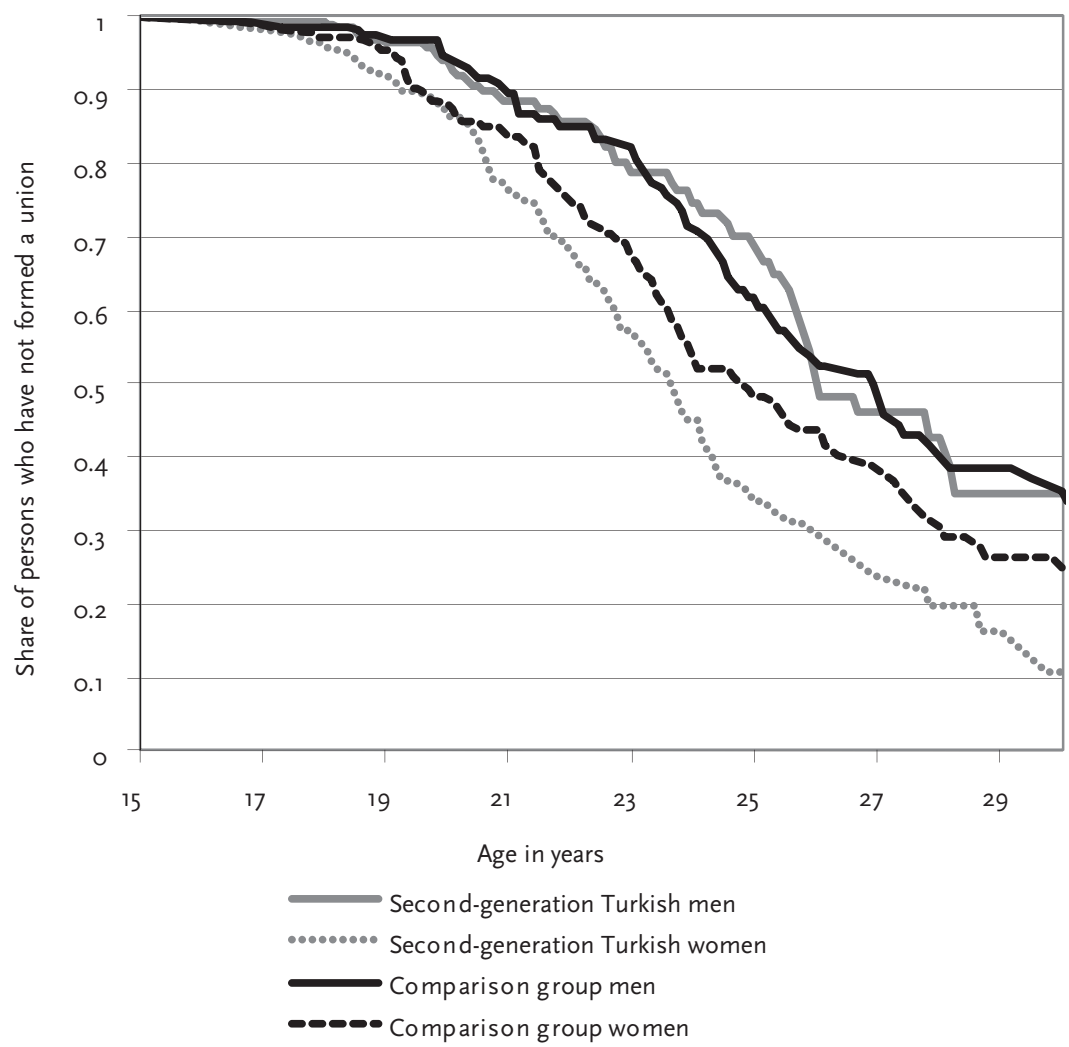

Source: TIES survey 2007-2008 
trend, thus enlarging the gender gap among our Turkish respondents. The following paragraphs examine this further.

In the two Austrian cities, both male and female second-generation Turks enter a first union much earlier than males and females in the comparison group (see figure 7.3c). Previous research on the majority group's transition to adulthood in Austria (Pfeiffer \& Vera Nowak 2001) has revealed the influence of the educational path chosen. As referred to in German, the 'dual system of vocational education', which consists of half-time education at school and half-time on-the-job training at a company, offers good access opportunities to a first job right after finishing one's education and at a relatively early age. Leaving the parental home and first union formation are thus timed in quite close succession. The earlier first union formation among second-generation Turks might at least partly reflect these respondents' much higher numbers in vocational education and the consequent earlier completion of education (which also means not entering into the dual system; for more details on educational choices, see chapter 5).

Figure 7.3C Transition to a first union in Austria

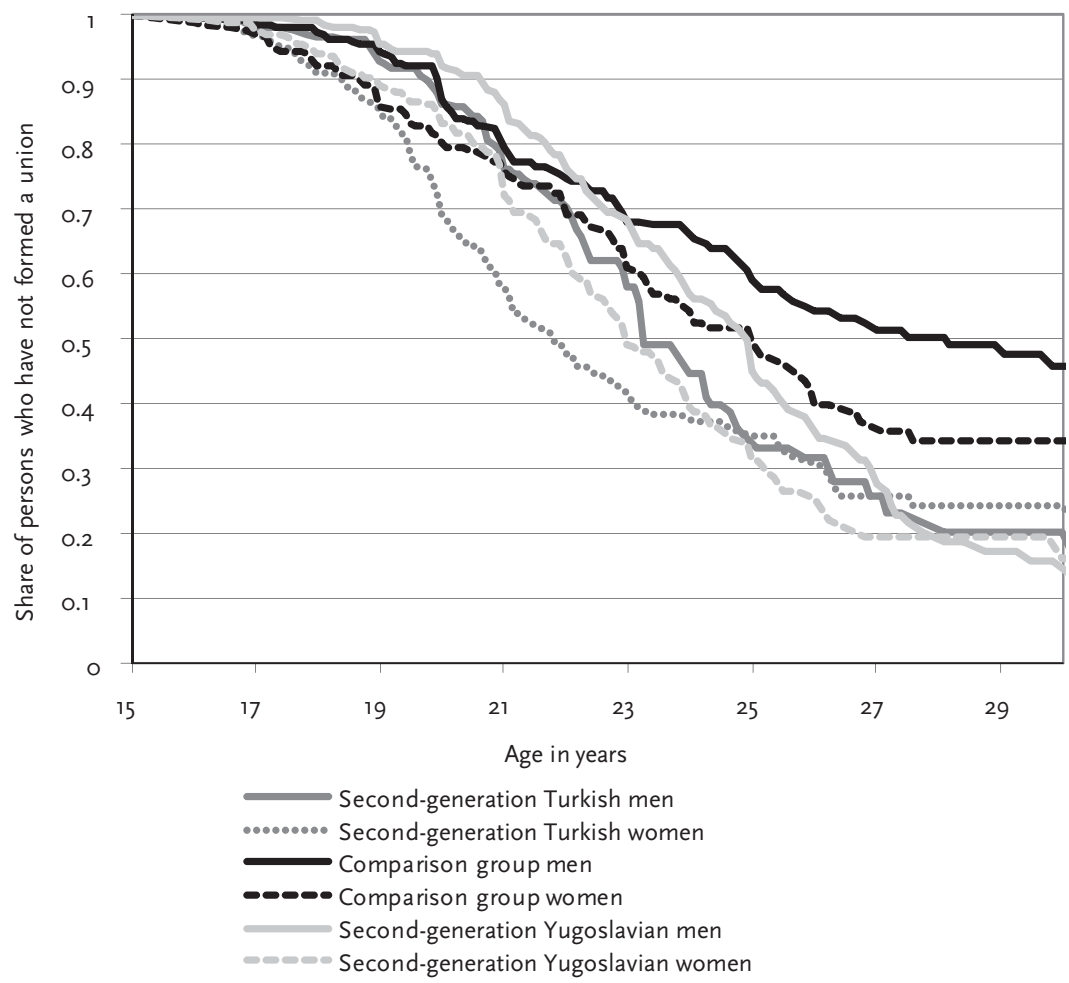

Source: TIES survey 2007-2008 
Germany has one of the latest patterns of entry into union. Leaving the parental home and first union formation occur, as in Austria, in close succession and after access to paid employment (Hullen 2001). Second-generation Turkish women enter earlier into their first union than the comparison group, but the gender difference is quite small compared to some other countries. $^{2}$

The Swiss case is similar to the German, albeit with a few differences (see figure 7.3e). Like Germany, Switzerland has a dual school system. Unlike in other European countries, however, first union timing for the comparison group is not accounted for by entrance into the labour market. Rather, it seems to be something chosen by the young adults themselves (Thomsin, Le Goff \& Sauvain-Dugerdil 2004). A relatively large share of the comparison group remains outside a union until age 30. Young secondgeneration Turkish women and men form their first union much earlier than the comparison group. Whereas in Sweden we found mainly gender differences and a relatively limited variation by origin, second-generation

Figure 7.3d Transition to a first union in Germany

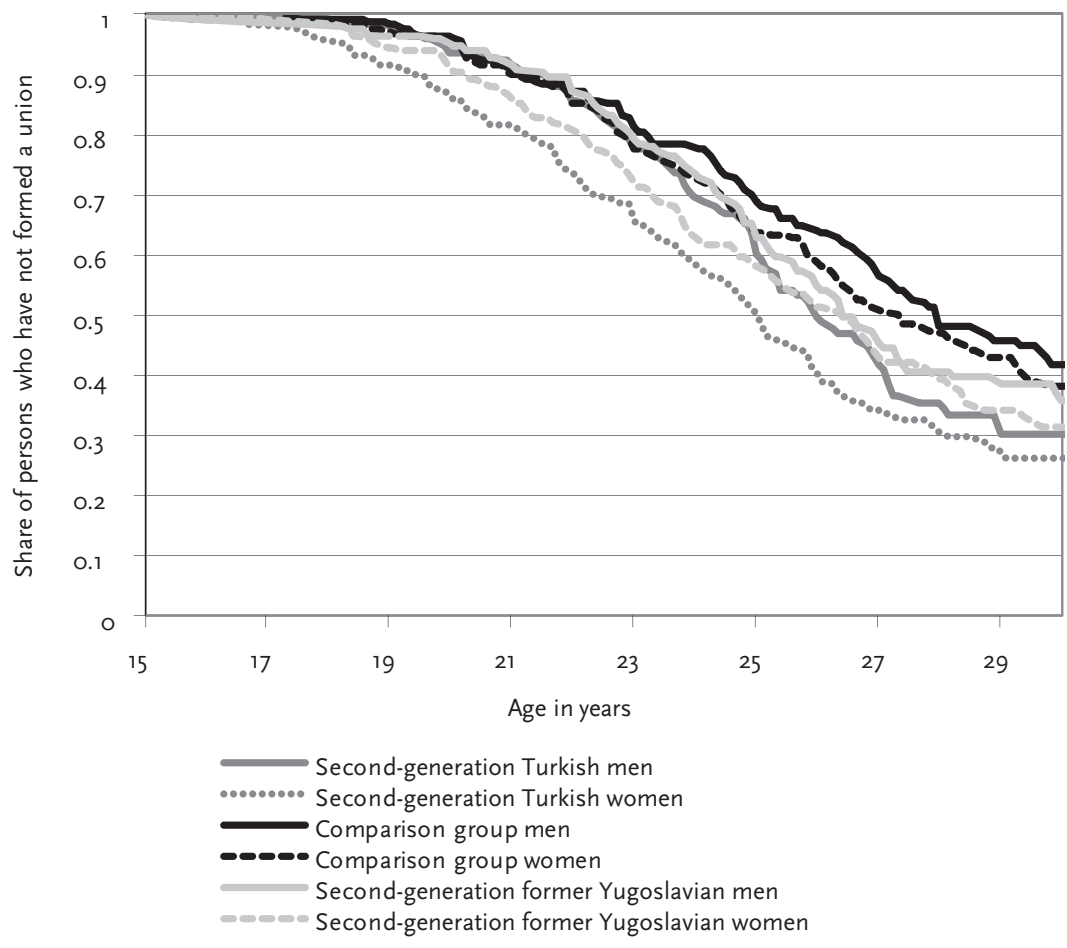

Source: TIES survey 2007-2008 
Figure 7.3e Transition to a first union in Switzerland

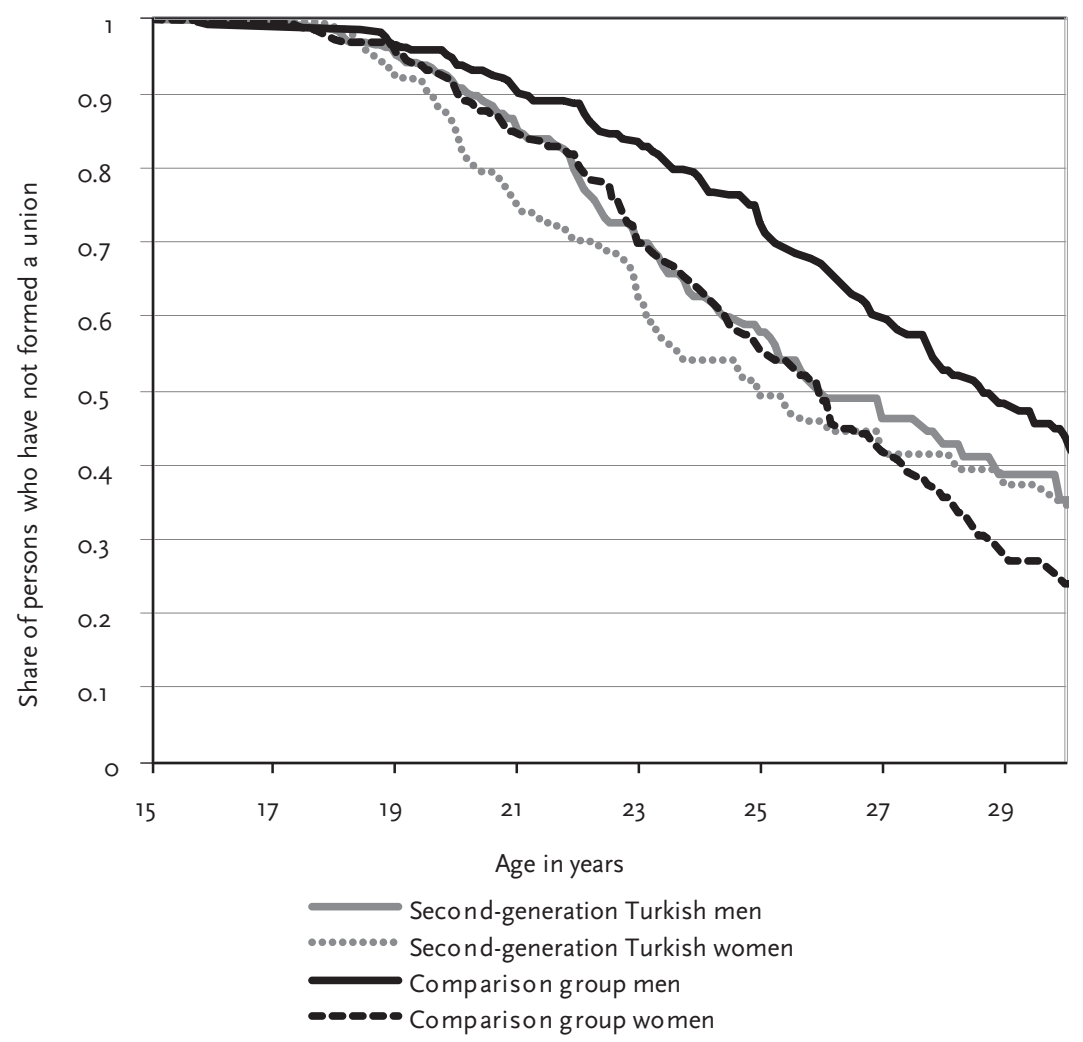

Source: TIES survey 2007-2008

Turks in Switzerland have almost identical patterns of first union formation. The relatively small gender differences among the second-generation Turks in Germany and Switzerland was not found in the other surveyed countries.

Belgium and the Netherlands show much commonality across all groups (see figures 7.6a and 7.6b in appendix). In both countries, second-generation Turkish women are the youngest to enter a first union; falling between them and the comparison group males are second-generation Turkish males and comparison group females. In the Netherlands, the union formation pattern of second-generation Moroccan women is close to that of comparison group women. By age 30, around a third of these women (like their male Moroccan and male comparison group peers) have still not formed a first union. 


\section{Factors influencing the transition to a first union}

The second stage in the event-history analyses focuses on mechanisms driving the start of a first union. We estimated piecewise-constant intensity regression models. All analyses were performed separately for men and women by origin group. Since we found largely similar patterns for men and women, we present here only the findings for women of different origins (for findings for men, see table 7.12a in appendix).

Table 7.3a shows clear differences in entry to a first union for women across the different countries. ${ }^{3}$ As presented above, comparison group women in all countries enter the first union later than women in Sweden (model 1). The transition to the first union occurs particularly late in Germany.

Model 2 adds a number of control variables such as birth cohort, education, religion, number of siblings, father's education and age. Previous studies have found that educational enrolment is associated with delaying the first union. However, the effects of the educational level seem to be of little importance in the comparison groups. Education only significantly postpones first union formation when respondents are still enrolled in some educational institution. Also, no effects were found for religious upbringing, the presence of siblings or father's education.

This picture looks different when we focus on second-generation Turks in various European countries. The first model includes only the respondents' age and country of residence. Among second-generation Turkish women, we found a postponed union formation tendency in France and, in particular, Germany and Switzerland (model 1). As this pattern highly resembles findings in the comparison groups, we see a potential correlation with factors of context to which both the majority groups as well as the second generations are exposed.

The second model introduces additional individual and family characteristics, thus neutralising the potential effects of differences between cities in the social composition of groups. For respondents of the same age, coming from the same level of education, social background and situation regarding educational enrolment, the likelihood of entering a first union remains lower in Germany and Switzerland than in the other surveyed countries. This indicates that in these countries national patterns of transition to adulthood are more influential. In all the countries, the likelihood of first union formation is lower for the second generation's younger birth cohort (i.e. those born between 1981 and 1990) than the older cohort (i.e. those born between 1970 and 1980). Being enrolled as a student is a significant factor in postponing union formation for second-generation Turkish women. The model shows no effect from the father's educational level; a reason may well be the very low educational level of the great majority of the fathers. 
Table 7.3a Relative risks in transition to a first union for comparison group and second-generation Turkish women

\begin{tabular}{|c|c|c|c|c|c|c|c|}
\hline \multirow{3}{*}{$\frac{\text { Variable }}{\text { Sweden (ref.) }}$} & \multicolumn{3}{|c|}{ Turkish second generation } & \multicolumn{4}{|c|}{ Comparison group } \\
\hline & Model 1 & \multicolumn{2}{|c|}{ Model 2} & \multicolumn{2}{|c|}{ Model 1} & \multicolumn{2}{|c|}{ Model 2} \\
\hline & 1 & 1 & & 1 & & 1 & \\
\hline France & 0.88 & 0.82 & & 0.65 & $* *$ & 0.65 & $* *$ \\
\hline The Netherlands & 1.17 & 0.98 & & 0.57 & $* * *$ & 0.58 & $* * *$ \\
\hline Germany & $0.72 *$ & 0.47 & $* * *$ & 0.44 & $* * *$ & 0.35 & $* * *$ \\
\hline Austria & 1.17 & 0.95 & & 0.67 & $* * *$ & 0.62 & $* *$ \\
\hline Switzerland & $0.68 *$ & 0.58 & $* *$ & 0.60 & $* * *$ & 0.57 & $* * *$ \\
\hline Belgium & 1.12 & 0.89 & & 0.55 & $* * *$ & 0.55 & $* * *$ \\
\hline
\end{tabular}

Birth cohort

1971-1980

1981-1990

$\begin{array}{rr}1 & 1 \\ 0.8 * & 1.05\end{array}$

Education

Primary/special education

Lower secondary

Apprenticeship

Upper secondary/

0.88

apprenticeship

Tertiary

$0.55 * \cdots$

0.83

Enrolment in education

Religion during childhood Muslim (ref.)

$\begin{array}{rr}1 & \text { n.a. } \\ 1.04 & 1 \\ 0.72 & 1.01\end{array}$

Christian

Number of siblings

0 (ref.)

1 or 2

$3+$

Father's education

Primary or less

$\begin{array}{rr}1 & 1 \\ 1.04 & 1.06 \\ 1.02 & 0.95\end{array}$

Tertiary

Age in years

\begin{tabular}{|c|c|c|c|c|c|c|c|}
\hline $18-20$ & 0.004 & $* * *$ & 0.005 & $* * *$ & 0.003 & $* * *$ & 0.004 \\
\hline $20-25$ & 0.012 & * & 0.016 & 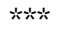 & 0.013 & $* * *$ & 0.014 \\
\hline $25-30$ & 0.011 & 粐次 & 0.013 & 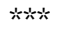 & 0.017 & $* * *$ & 0.020 \\
\hline $30-35$ & 0.013 & 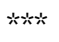 & 0.015 & $* * *$ & 0.013 & $* * *$ & 0.014 \\
\hline Log likelihood & -1390.7 & & -1151.7 & & -1332.8 & & -1227.0 \\
\hline
\end{tabular}

$*=5 \% ; * *=1 \% ; * * *=0.1 \%$

Note: Education variables each contain a small number of missing values without significant impact

Source: TIES survey 2007-2008 
The effect of an Islamic upbringing seems no different from that of being brought up with another religion or in a non-religious context. Family size, however, as indicated by the number of siblings, is clearly related to union formation. Second-generation Turkish women with many siblings are considerably more likely to have entered a union than those with few or no siblings. This could indicate that families with more children hold more traditional views on gender roles and the timing of union formation. An alternative explanation could be that in large families domestic overcrowding gives daughters an incentive to move out, thus living with a partner sooner than those who have no siblings at home.

Our findings on second-generation Moroccans, as studied in the Netherlands and Belgium, are summarised in the appendix (for women, see table 7.12b; for men, see table 7.12c). Among the women in this group, education was found to be an important factor: namely, higher levels of educational attainment led to union formation postponement. Chances of entering a union were again lower for the younger cohort of second-generation Moroccan women. Other family characteristics did not seem to be significant determinants.

Our findings on second-generation former Yugoslavian women, as studied in Germany and Austria, are also summarised in the appendix (for women, see table 7.12b; for men, see table 7.12c). Again, we find clear educational differences that are fully consistent with what was found for the second generation of other origins: enrolment in education and higher educational attainment are both associated with lower transition rates into a union. Once again, we see that having more siblings significantly increases the likelihood of entering a union. At the same time, the father's educational level and religion do not have the expected effect and seem unrelated to the first union formation of female second-generation former Yugoslavians.

In sum, educational attainment and sibling numbers are the most important factors for the timing of first unions in all three second-generation groups, but not for the comparison groups. The weaker role of education for the comparison groups may have to do with the fact that postponing union formation is a sort of generalised pattern in the majority population, whereas the educated second generation may be forerunners at adopting new union formation behaviour. The same applies to sibling numbers: since having many siblings is quite an exception in the majority population, this cannot play a role comparable to the one it does for second-generation women. For second-generation men, educational attainment seems to have less impact on union formation behaviour. 


\subsection{Type of first union: Marriage and unmarried cohabitation}

Many young Europeans nowadays start a union by living together in an unmarried partnership. Scholars have noted that young adults delay commitments and are more individualised than in the past (Lesthaeghe \& Van de Kaa 1986), trends which have been linked to the emergence of less standardised life courses and new types of partner relationships (Elzinga \& Liefbroer 2007). Directly entering into marriage has become much less common and, in many European countries, unmarried cohabitation has established itself as a recognised form of partnership alongside marriage. Also, a substantial proportion of young adults continues to marry after having cohabited with a partner for some time (Billari \& Wilson 2001). The extent of unmarried cohabitation, however, varies widely across Europe. It is most common in Sweden, France and Germany (Billari \& Wilson 2001).

By contrast, most immigrants originate from countries where the first union is almost without exception a marital union. Few studies, however, have focused on the type of union chosen specifically by the second generation in different contexts. De Valk (2007) has shown that premarital cohabitation is the preferred option for a growing proportion of young adults of Turkish and Moroccan origin in the Netherlands, whereas Milewski and Hamel (2010) have shown that young men and women of Turkish origin in France do prefer marriage over consensual union. Are the young adults interviewed for the TIES survey opting for unmarried cohabitation - as are the majority populations where they live - or for marital union? Tables $7.4 \mathrm{a}$ and $7.4 \mathrm{~b}$ provide a descriptive overview of the findings.

The vast majority of second-generation Turkish women's first unions are marital. Proportions of marital unions are highest in Belgium (95 per cent) and France ( 90 per cent); this reveals the strong influence of Turkish norms on the second generation's affective life - notably in France, given that unmarried cohabitation is quite universal here. The lowest rate of marriage is found in Switzerland, even though it remains high at 73 per cent. For second-generation Turkish men, percentages are on the whole lower than for women. The lowest shares are again found in Switzerland, where only 60 per cent live with a spouse, while the rate of consensual unions in the comparison group is not higher in this country than any others. Following Switzerland, Sweden has the second-lowest country rate of marriage among second-generation Turks. In other words, in these two countries, young second-generation Turkish adults follow the 'Turkish pattern' of marriage to a lesser extent than others.

For second-generation Moroccans - although marriage again accounts for the majority of first unions - percentages of those cohabiting are substantial, particularly for men, and more so in the Netherlands than in Belgium. The difference between the countries of residence is remarkable, 


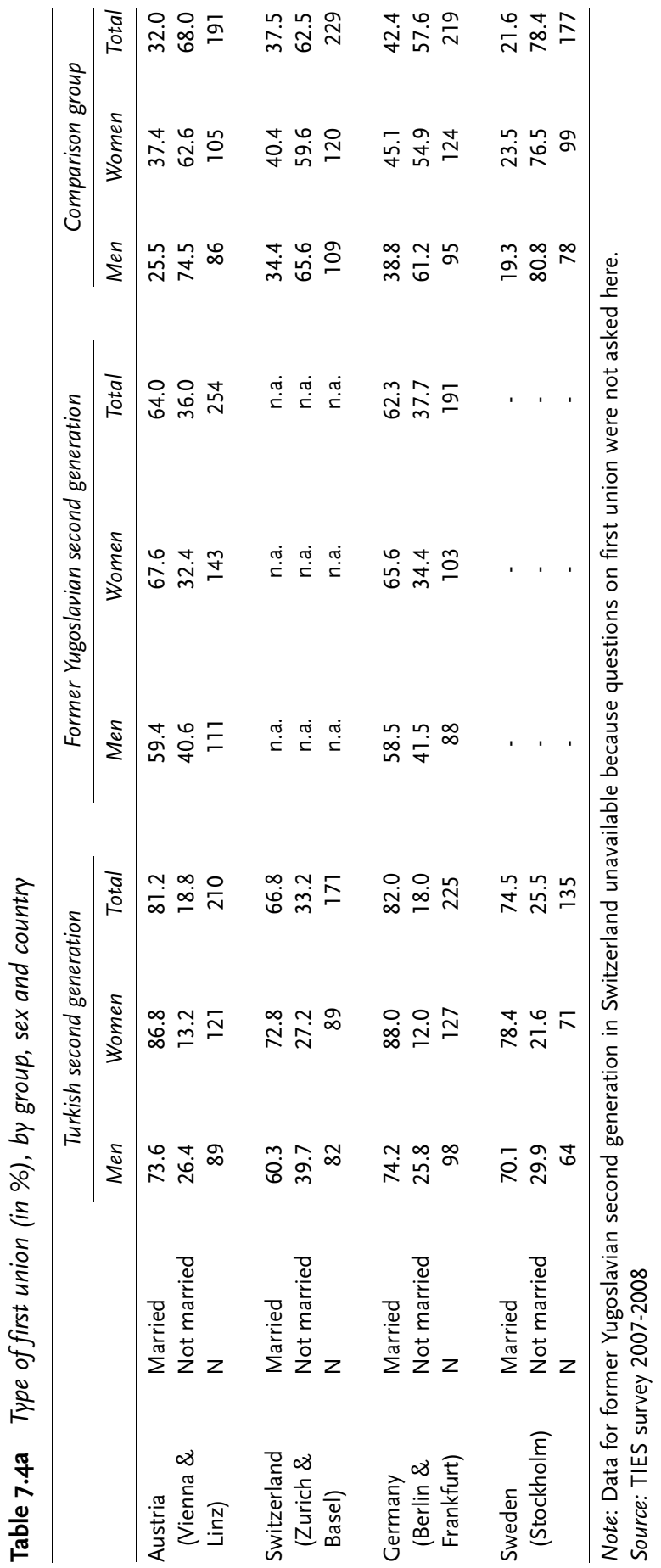




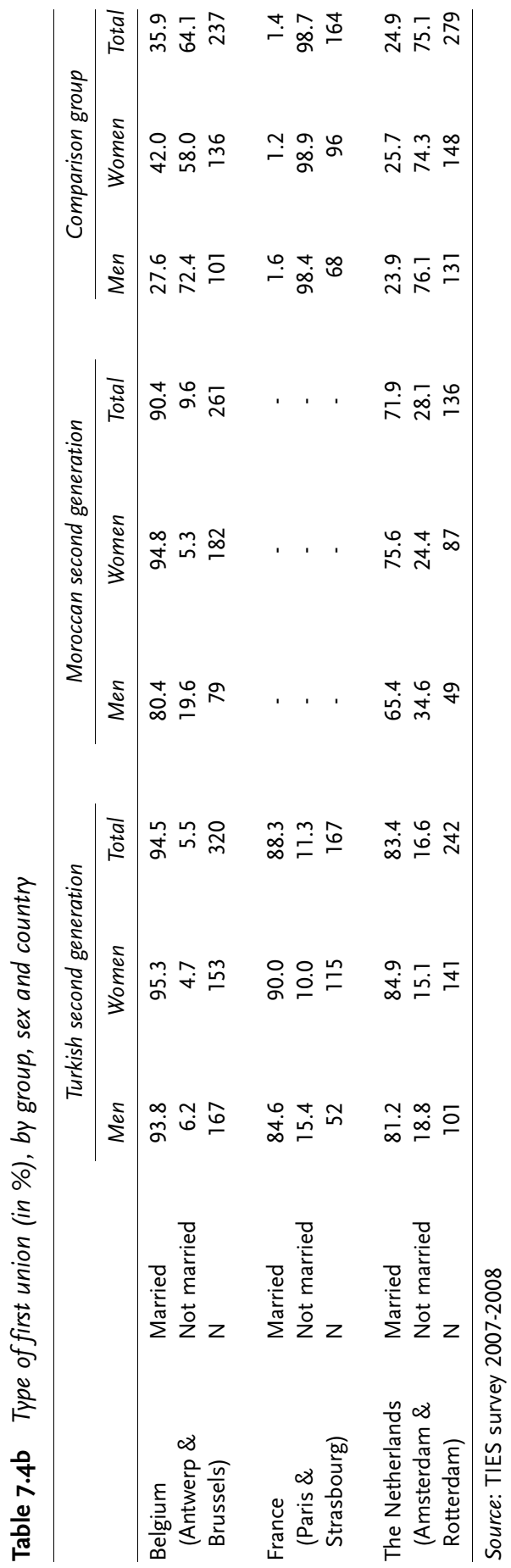


with second-generation Moroccan men and women in the Netherlands much more frequently cohabiting than their counterparts in Belgium.

Of the three origin groups, the least likely to form marital unions is the second-generation former Yugoslavians (see table 4a). Although cohabitation is much more common in this group than in the other two second generations, the shares of cohabitants are still below those in the respective countries' majority populations. Between one third and half of former Yugoslavian second-generation men formed an unmarried cohabiting union. For women, too, unmarried cohabitation is far from exceptional. The proportion of cohabiting unions is slightly higher for both male and female respondents in Germany than in Austria.

\section{Factors shaping the choice for marriage versus unmarried cohabitation}

The choice for marriage versus unmarried cohabitation has been linked in the literature to both individual preferences and parental socialisation. But as Kalmijn (1998) has pointed out, opportunity structures also impact union formation. It is relevant that state rules for acquiring a residency status and citizenship may influence the second generation's choice of type of union if their partner is an immigrant. In the majority of European countries, marriage still confers more extensive rights than cohabitation; a legal permit to stay is hard to obtain through other means. These legal issues can be expected to be more significant for second-generation Moroccans and Turks than for those of former Yugoslavian origin. At the same time, cultural aspects may play a role in people's preference for marriage, especially when it comes to the importance attached to female chastity. These possible explanatory factors should be kept in mind when interpreting the following findings on the preferences for marriage or cohabitation.

Our analyses of the second generation's choice of union focuses mainly on individual and family characteristics, as regularly applied in the literature. Table 7.5a shows findings of the logistic regression analyses. The first model looks at the effect of respondents' social characteristics (sex, place of residence, cohort and educational level) on the likelihood of marriage over cohabitation. The second model adds the respondents' family characteristics (religion practised during childhood, number of siblings and father's level of education). The two models are presented separately for the comparison group and second-generation Turks.

The first model's findings for the comparison groups show that women are more likely than men to have formed a marital union, though the significance of this observation is weak. We also find cross-national differences in likelihood of being married when differences in education level and age of the studied populations across cities are neutralised. At the same age and with the same education level, respondents from the comparison group are more than twice as likely to be in a married union in Germany, 
Table 7.5a Factors influencing marriage versus unmarried cohabitation for Turkish second-generation and comparison group, by group (odds ratios)

\begin{tabular}{|c|c|c|c|c|c|c|c|c|}
\hline \multirow[b]{2}{*}{ Variable } & \multicolumn{4}{|c|}{ Turkish second generation } & \multicolumn{4}{|c|}{ Comparison group } \\
\hline & \multicolumn{2}{|c|}{ Model 1} & \multicolumn{2}{|c|}{ Model 2} & \multicolumn{2}{|c|}{ Model 1} & \multicolumn{2}{|c|}{ Model 2} \\
\hline Men & 1 & & 1 & & 1 & & 1 & \\
\hline Women & 1.83 & whr & 1.8 & $* *$ & 1.36 & $*$ & 1.43 & {$[0.007]$} \\
\hline Sweden & 1 & & 1 & & 1 & & 1 & \\
\hline France & 1.52 & & 1.22 & & 0.08 & $* *$ & 0.06 & 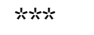 \\
\hline The Netherlands & 1.49 & & 1.11 & & 1.16 & & 1.17 & \\
\hline Germany & 0.96 & & 0.73 & & 2.60 & $* * *$ & 2.44 & $* *$ \\
\hline Austria & 0.99 & & 0.93 & & 1.63 & & 1.49 & \\
\hline Switzerland & 0.62 & $*$ & 0.56 & {$[0.059]$} & 2.16 & $* *$ & 2.40 & $* *$ \\
\hline Belgium & 4.30 & 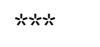 & 4.03 & $* *$ & 2.04 & $*$ & 2.06 & * \\
\hline \multicolumn{9}{|l|}{ Birth cohort } \\
\hline $1971-1980$ & 1 & & 1 & & 1 & & 1 & \\
\hline $1981-1990$ & 0.52 & 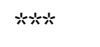 & 0.52 & 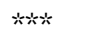 & 0.19 & $* * *$ & 0.18 & 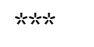 \\
\hline \multicolumn{9}{|l|}{ Education } \\
\hline Primary/special education & 1.32 & & 1.33 & & 0.35 & & 0.33 & \\
\hline Lower secondary & 1 & & 1 & & 1 & & 1 & \\
\hline Apprenticeship & 1.49 & & 1.52 & {$[0.098]$} & 1.33 & & 1.37 & \\
\hline $\begin{array}{l}\text { Upper secondary/ } \\
\text { apprenticeship }\end{array}$ & 0.93 & {$[0.086]$} & 1.22 & & 1.10 & & 1.08 & \\
\hline Tertiary & 0.53 & 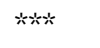 & 0.70 & & 0.93 & & 1.03 & \\
\hline \multicolumn{9}{|l|}{ Religion during childhood } \\
\hline Muslim & & & 2.06 & $* * *$ & & & 21.4 & $* *$ \\
\hline None or other & & & 1 & & & & 1 & \\
\hline \multicolumn{9}{|l|}{ Number of siblings } \\
\hline 0 & & & 1 & & & & 1 & \\
\hline 1 or 2 & & & 2.41 & $*$ & & & 0.73 & {$[0.095]$} \\
\hline $3+$ & & & 3.50 & $* *$ & & & 0.97 & \\
\hline \multicolumn{9}{|l|}{ Father's education } \\
\hline Primary or less & & & 1 & & & & 1 & \\
\hline Secondary & & & 0.92 & & & & 0.95 & \\
\hline Tertiary & & & 0.32 & $* *$ & & & 0.65 & \\
\hline Log likelihood & -609.5 & & -527.5 & & -787.9 & & -733.4 & \\
\hline
\end{tabular}

$*=5 \% ; * *=1 \% ; * * * *=0.1 \%$.

Notes: Education variables each contain a small number of missing values without significant impact (not displayed here).

Source: TIES survey 2007-2008 
Switzerland and Belgium than comparison group respondents in Sweden or France. Differences between the other countries are not significant. We also find that the younger cohort is less often married than the older cohort, indicating that marriage is still losing its importance, though no overall differences by education level are found. Introducing parental background and socialisation characteristics in model 2 does not change these findings. In the comparison group choice of type of first union appears unrelated to either parental education or sibling numbers.

The factors influencing the likelihood of marriage are not exactly the same for second-generation Turks. Women are more likely to have gotten married than men in this group, but this gender gap is much more pronounced than in the comparison group and appears to be highly significant. Moreover, the fact remains after controlling for family background characteristics in model 2. In sum, at the same age, with the same education level, same social background, same number of siblings and same religion during childhood, second-generation Turks are far more likely to be married in Belgium than in any other country (with Sweden as the reference category). The higher proportion of marriages in Belgium is thus not due to a higher proportion of lower-educated people there. Important factors here could be the level of group cohesion, endogamy and, partially related to this, likelihood of choosing a partner from Turkey. (We will come back to this in the next paragraph.) Switzerland also appears to be a country where the likelihood of marriage for young second-generation Turkish men and women is lower than in Sweden. This reveals how the national norm of unmarried cohabitation here influences the second generations' practices, which does not seem to be the case in the other countries, where observed variations of marriage rates are mainly due to variations in respondents' education levels across cities.

Our analyses, furthermore, point to the younger cohort of second-generation Turks as being less likely to be married, with the same holding true for those with tertiary education. Thus, marriage is slightly tending to lose its importance among second-generation Turks, though this process is less pronounced here than in the comparison groups. As far as the variables in model 2, both religion and number of siblings are factors that encourage marriage; a Muslim upbringing increases the likelihood of marriage, as does having three or more siblings. Both factors could be indicators for the degree to which parents endorse more traditional values concerning union formation. Including the father's educational level in the analysis makes the individual level variables less important. Those with a highly educated father more often formed unmarried cohabiting unions.

The analyses were replicated for second-generation Moroccans and former Yugoslavians (see table 7.13 in appendix). Again, second-generation Moroccans in Belgium have much higher chances of forming a married union than their counterparts in the Netherlands (model 1). This finding 
remains robust after controlling for other factors in model 2. This suggests that the Belgian context is an important additional explaining factor alongside the characteristics of the diasporic community mentioned in the above paragraph (Timmerman, Lodewijckx \& Wets 2009). For second-generation former Yugoslavians, we do not find country differences after controlling for other factors.

Again, women in both Moroccan and former Yugoslavian second generations whom we surveyed were more likely to have been married than men. Religion is a major explanatory factor for a person's type of union; being raised in a Muslim tradition significantly increases the likelihood of having married. The same is true for having three or more siblings.

Our analyses show interesting gender differences that persist for all groups and in all cities. At the same time, clear differences exist between places of residence. With the available data it is hard to isolate the factors at work here. Of potential relevance are an individual's migration history, the partner's origin and the union formation behaviour of the majority population. Our data also suggest that individual orientation towards marriage (as indicated by educational level and socialisation characteristics) remains important for all groups and in all settings. A lower propensity to marry found among the younger cohort may indicate a process of change that is underway within each of the origin groups. As Lesthaeghe (2000) pointed out, attitudes concerning family and union formation involve core values that are inevitably slow to change. The substantial proportions in the second generation who are already opting for cohabitation - with an even larger proportions in the younger cohort - may well be an indication for how union formation will evolve in the future among second-generation young adults in Europe.

\section{Leaving the parental home}

To better understand how the first union is connected to other major events in the transition to adulthood, we present reasons for leaving the parental home. One of the key considerations for leaving the parental home among young adults of the majority group in Europe was 'living independently'.

Our findings on the type of partnerships are also reflected in the reasons young adults gave for leaving the parental home.

Tables 7.6a and 7.6b indicate the percentage of young adults who stated that they left home to form a union, either marriage or cohabitation, to be independent, to study or work (as there were several answers possible, the total sums up to more than 100 per cent). We provide information by origin, sex and country of residence. The majority of the comparison group members chose 'living independently', 'to study' or 'to work' as their main reasons for leaving the parental home (around 70 per cent). Differences between men and women are small. 


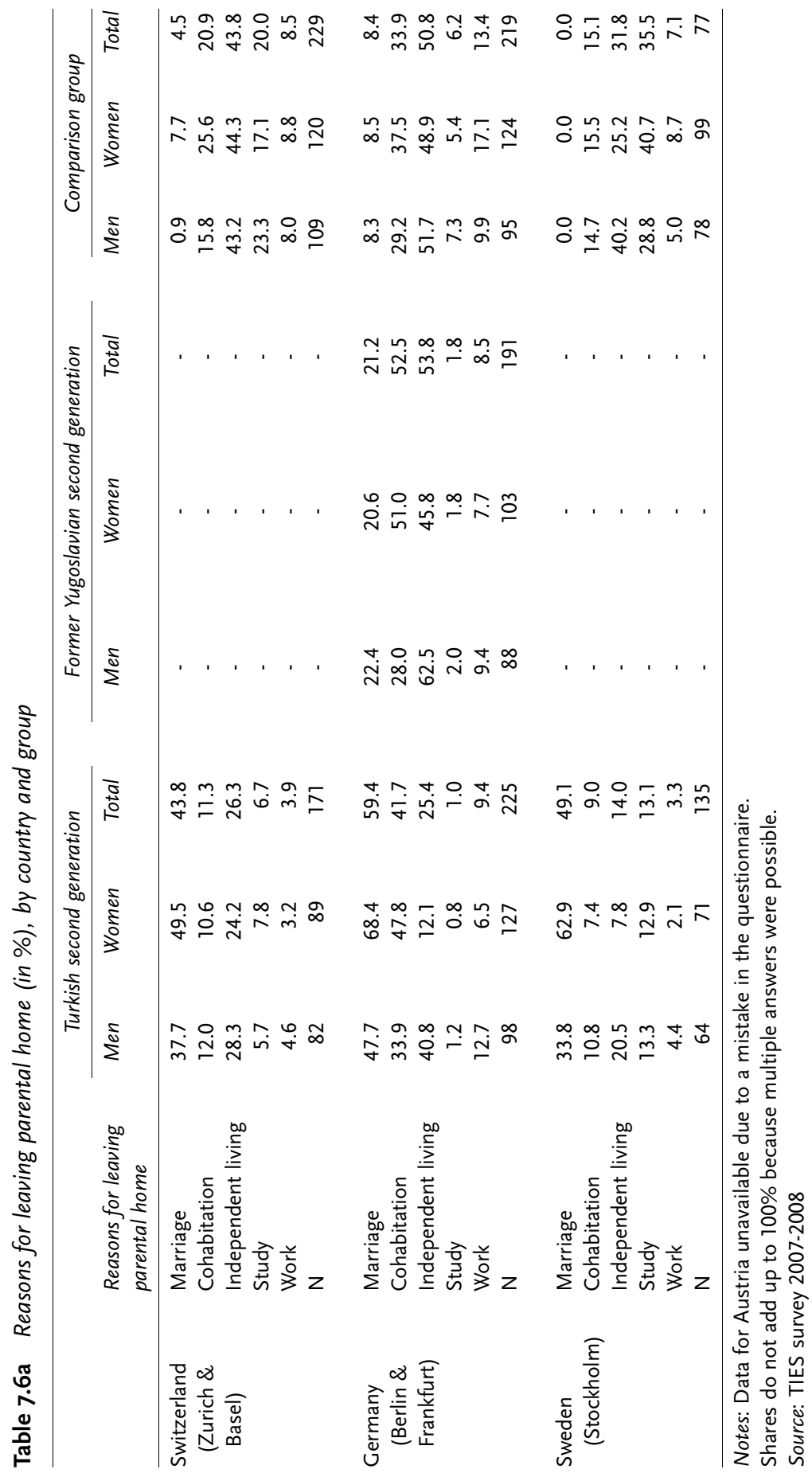




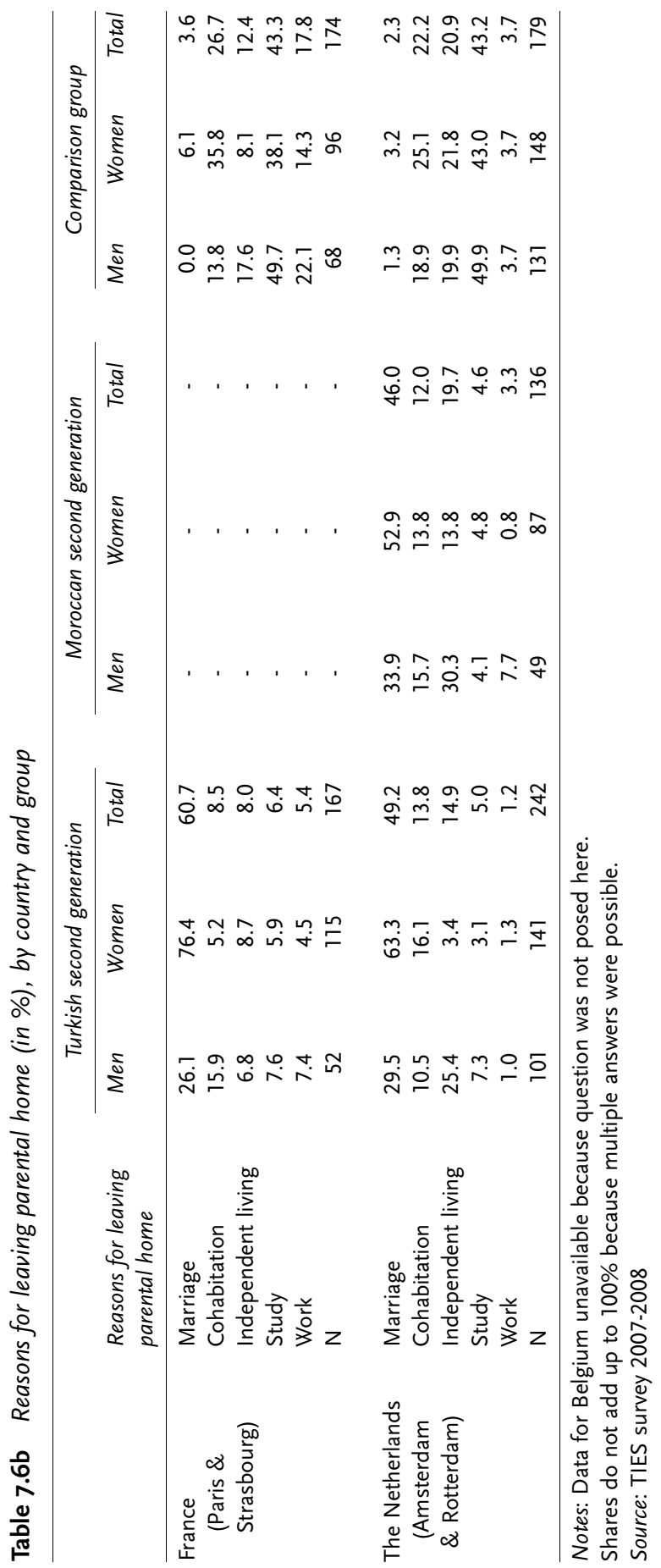


The scenario is radically different for second-generation Turks. Only 20 to 30 per cent left the parental home for these same reasons, the main being union formation; this was particularly pronounced for women and for entering marriage rather than cohabitation. However, second-generation Turks in Sweden and Switzerland seem to be the forerunners of a new pattern. 'Living independently' was the highest-scoring reason for secondgeneration Turkish women in Switzerland (24 per cent); 'to study' was highest-scoring for their counterparts in Sweden (13 per cent).

Young former Yugoslavian adults occupy an intermediate position between those described above. Cohabitation is the major reason for leaving the parental home, but getting married is more common among them than it is for the comparison group. Moroccans in the Netherlands (no data available in Belgium on this issue) largely follow the Turkish patterns.

\subsection{Partner choice: Different social factors at play}

Surveys on immigrants or their descendants that explore partner choice generally focus on intermarriage. This tradition can be traced back to works on immigrant assimilation by sociologists in the Chicago School. In the first half of the twentieth century, North American researchers considered frequency of intermarriage the most reliable indicator of assimilation (Safi 2008), though it was not until 1964 that Gordon developed the first theoretical exposition of the relationship between intermarriage and assimilation. The implicit idea is that children of mixed couples have a weaker attachment to their immigrant parents' group of origin. It is also argued that intermarriage is a consequence of dissolving boundaries between immigrant groups and the majority population, since members of the other group are regarded as acceptable partners (Perlman \& Waters 2004). As Kalmijn (1998) has observed, however, it takes two to form a mixed couple. If one group is open to intermarriage though the other not, endogamy continues to prevail in both groups. Contrasting with the Chicago School research on intermarriage, more recent studies show that high rates of endogamy may coincide with successful integration (which is, for instance, the case of Jews and Asians in the United States). On the other hand, economically vulnerable groups may have high rates of exogamy (as is the case for the population of West Indian origin in the United Kingdom; see Muttarak 2003). Though we know about relations between immigrants and their partners from the majority population, there is still hardly any theorising on intermarriage between different immigrant groups. In sum, the debate is still inconclusive about the interpretation of intermarriage and its consequences (Song 2009).

The following section examines different factors in the choice of one's partner. They include educational and religious homogamy (Uunk 1996), 
where people meet future partners and what their ethnic or migrational background is, indicating rates of intermarriage.

\section{Educational homogamy}

Sociologists and demographers have shown how choosing a partner is not solely a personal matter (Girard 1964; Bozon \& Héran 1989; Kalmijn 1991). The idea of partner selection based on a romantic model of mutual love is, at best, incomplete and, at worst, an illusion: in many cases partner choice is governed by broader contextual and social characteristics, such as the individuals' occupations and those of their parents. Girard (1964) showed for France in the early 1960s how individuals generally preferred a partner with similar personal background characteristics and with parents whose occupations were close to his or her own parents' place in the social hierarchy of occupations. In general, high levels of socio-economic homogamy are frequently observed (Kalmijn 1998).

Analysts of social stratification argue that the personal characteristics of couples are good indicators of how open or closed groups in society are. The existence of exogamous couples (with respect to origin) and heterogamous couples (with respect to occupation or education) is evidence that groups see each other as equals. One of the main factors of stratification in Western societies today is education. Recent studies on socio-economic homogamy are based on the partners' educational level rather than their family backgrounds (traditionally accounted for by the father's occupation). Indeed, the role social background plays in partner choice has decreased in most industrialised countries (Ultee \& Luijkx 1990). Our analyses are thus also based on the educational levels of second-generation couples. Educational experience has become an important proxy for cultural capital and taste as well as socio-economic success - both of which impact partner choice (see Kalmijn 1994).

Our analysis distinguishes three levels of education. Level 1 corresponds to having left school after lower secondary level. Level 2 corresponds to having had higher secondary education or an apprenticeship. Level 3 corresponds to tertiary education. Tables $7.7 \mathrm{a}$ and $7.7 \mathrm{~b}$ show the correlation of the interviewees' education (I) with their partners' educational level (P). Results are presented by sex and origin group for each country.

In all the countries' comparison groups, educational homogamy exceeds 59 per cent. It is highest in Belgium and France, where, respectively, 77 per cent and 70 per cent of the couples have the same level of education. Living in these two countries' big cities appears to increase individuals' likelihood of forming a couple within their own social milieu; it also indicates relatively rigid social stratification. As shown in previous studies, men tend to be more highly educated than their female partners. We observe this especially for the comparison group in the German and Swiss 
Table 7.7a Educational homogamy of the current union (in \%), by country and group

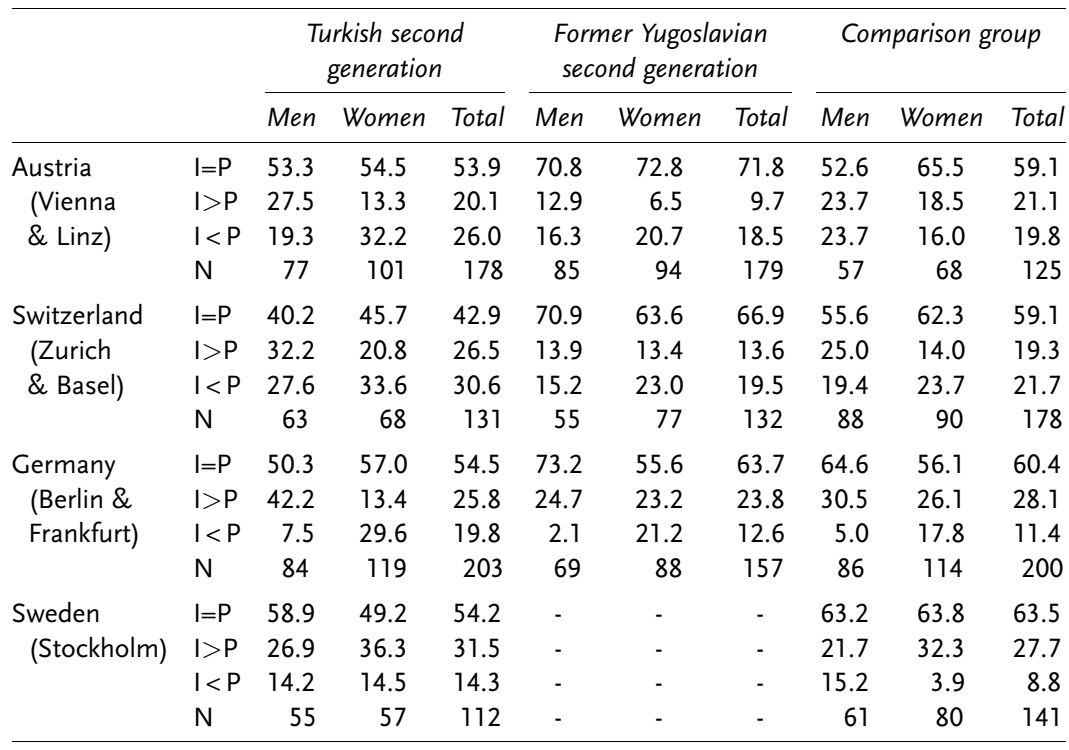

Table 7.7b Educational homogamy of the current union (in \%), by country and group

\begin{tabular}{|c|c|c|c|c|c|c|c|c|c|c|}
\hline & & \multicolumn{3}{|c|}{$\begin{array}{l}\text { Turkish second } \\
\text { generation }\end{array}$} & \multicolumn{3}{|c|}{$\begin{array}{c}\text { Moroccan } \\
\text { second generation }\end{array}$} & \multicolumn{3}{|c|}{ Comparison group } \\
\hline & & Men & Women & Total & Men & Women & Total & Men & Women & Total \\
\hline \multirow{4}{*}{$\begin{array}{l}\text { Belgium } \\
\text { (Brussels \& } \\
\text { Antwerp) }\end{array}$} & $\mathrm{I}=\mathrm{P}$ & 41.6 & 45.4 & 43.6 & 43.5 & 50.9 & 47.7 & 76.7 & 64.6 & 70.0 \\
\hline & $\mathrm{I}>\mathrm{P}$ & 46.0 & 33.6 & 39.7 & 32.7 & 29.3 & 30.7 & 11.9 & 30.2 & 22.0 \\
\hline & $\mathrm{I}<\mathrm{P}$ & 12.3 & 20.9 & 16.7 & 23.9 & 19.9 & 21.6 & 11.4 & 5.2 & 8.0 \\
\hline & $\mathrm{N}$ & 157 & 137 & 294 & 68 & 146 & 214 & 78 & 117 & 195 \\
\hline \multirow{4}{*}{$\begin{array}{l}\text { France } \\
\text { (Paris \& } \\
\text { Strasbourg) }\end{array}$} & $\mathrm{I}=\mathrm{P}$ & 57.2 & 38.4 & 44.9 & - & - & - & 84.2 & 71.5 & 77.4 \\
\hline & $I>P$ & 29.2 & 31.3 & 30.5 & - & - & - & 5.0 & 23.0 & 14.7 \\
\hline & $\mathrm{I}<\mathrm{P}$ & 13.6 & 30.4 & 24.6 & - & - & - & 10.8 & 5.5 & 8.0 \\
\hline & $\mathrm{N}$ & 48 & 100 & 148 & - & - & - & 57 & 77 & 134 \\
\hline \multirow{4}{*}{$\begin{array}{l}\text { Netherlands } \\
\text { (Amsterdam } \\
\text { \& Rotterdam) }\end{array}$} & $\mathrm{I}=\mathrm{P}$ & 48.0 & 56.5 & 52.7 & 47.6 & 38.8 & 42.0 & 63.1 & 56.2 & 59.6 \\
\hline & $I>P$ & 31.6 & 18.9 & 24.5 & 22.3 & 25.3 & 24.0 & 19.4 & 32.5 & 26.1 \\
\hline & $I<P$ & 20.4 & 24.6 & 22.8 & 30.1 & 36.0 & 34.0 & 17.5 & 11.3 & 14.3 \\
\hline & $\mathrm{N}$ & 91 & 126 & 217 & 37 & 70 & 107 & 103 & 114 & 217 \\
\hline
\end{tabular}

Notes for $7.7 a$ and $7.76: \mathrm{I}=$ interviewee's level of education; $\mathrm{P}=$ partner's level of education $\mathrm{I}=\mathrm{P}$ educational homogamy

$\mathrm{I}>\mathrm{P}$ interviewee has higher level

$\mathrm{I}<\mathrm{P}$ partner has higher level

Source: TIES survey 2007-2008 
cities. In Switzerland, for example, 25 per cent of the men versus only 14 per cent of the women are more highly educated than their partners. In France, Belgium, the Netherlands and Sweden, the situation is reversed: more couples feature women as the more highly educated of the two. This is particularly pronounced in Belgium and France, where the proportion of hypergamous (marrying a partner of lower social status) women is, respectively, three and five times higher than that of hypergamous men. ${ }^{4}$

In all countries, homogamous couples are much less common among second-generation Turks. The differences are most marked in the French and Belgian cities. While 84 per cent of the men and 71 per cent of the women in the French comparison group live as homogamous couples, this is only the case for 57 per cent of the men and 38 per cent among secondgeneration Turks. Their counterparts in the Belgian cities are 41 per cent for men and 45 per cent for women versus the comparison group's 76 per cent for men and 64 per cent for women. The same observation applies to second-generation Moroccans living in the Dutch and Belgian cities. Second-generation former Yugoslavians, however, stand out, having much higher levels of homogamy than the comparison groups in Austria, Germany and Switzerland. Yet, some caution is needed when interpreting these differences. Research on social homogamy has shown that more highly educated groups tend to be more homogamous than lower educated groups. The differences we observe by origin may thus be the result of structural effects arising from educational level variation across the groups in each city (see chapter 5). These results on educational homogamy argue for a more in-depth examination of how the second generation meets partners.

\section{Meeting place and family influences}

The Choice of a Spouse survey conducted in 1959 by Girard at the French National Institute for Demographic Studies (INED) provided a quantitative picture of the strength of social homogamy among French couples at that time. Thirty years later, two other demographers from INED conducted the Formation of Couples survey (Bozon \& Héran 1989), which gave special attention to partners' friendship networks and where people met their partners. This approach was also applied in other quantitative surveys on partner choice (e.g. Lampard 2007; Kalmijn \& Flap 2001). It revealed a strong correlation between the places where people meet and the social background of the people who frequent them, as well as associations with specific values, norms or tastes.

Partner choice is also the result of interactions between young adults and their parents. Most parents express expectations concerning the characteristics of their child's future partner, stressing, for example, the need to find someone with a stable job. The origin of the partner may also be a 
topic for discussion within families. People usually know whether their parents would accept or refuse someone from a different origin group or religion. But parents in present-day Europe have lost much power to influence, if not control, their children's choice. Nevertheless, most individuals orient partner choice according to anticipated acceptability by their parents. Social homogamy today is the result of new practices based on individuals with the same social background and characteristics who likely belong to the same networks and partake in the same activities, such as leisure pursuits. Since most choose partners from within their own network, they often share social characteristics.

Bozon and Héran (1989) constructed a classification scheme of places people meet their future partners, based on the type of meeting places most frequently associated with homogamy. They showed that members of the highest social classes tend to meet their partners in self-selective places, such as at school or university, in clubs and political parties, at the workplace, sports centres and holiday resorts. The workplace is an especially significant way for civil servants to meet future partners. The working class more often meet their partners in public places in the neighbourhood, at shopping centres, parks, movie theatres and bars. A third category in the scheme encompasses social networks of friends and family members.

Given the particular situation of second-generation Turks and Moroccans, the TIES survey distinguished between the individual's own network (identified by the response 'through friends') from the family network ('through my parents', 'at a family gathering' or 'on holiday in my parents' home country') when asking where respondents met their partners. The family network responses would indicate a relatively strong, if indirect, influence by the family on partner choice. The family network fosters an environment that is proximate to the first generation's own social milieu, where parental control can still be effective. The survey also included the response 'through an introduction by my parents', an answer that hints at parents' direct influence. Tables $7.8 \mathrm{a}$ and $7.8 \mathrm{~b}$ present the results for the different meeting place categories.

In all the countries, 20 to 40 per cent of the comparison group members met partners-to-be through mutual friends. Another third met their partners at school or university, at work or in an association of some sort. In other words, around two thirds found their partners in places qualified as either private or self-selective, which corresponds to practices among the educated that result in high rates of social homogamy. Only around one fifth of the introductions took place in public places such as cinemas and bars, on the street and in the neighbourhood. Moreover, family influence appears very limited: introduction to one's future spouse by parents is almost nonexistent (less than 1 per cent), while the indirect family influence amounts to 10 per cent. No significant gender differences are observed in the 


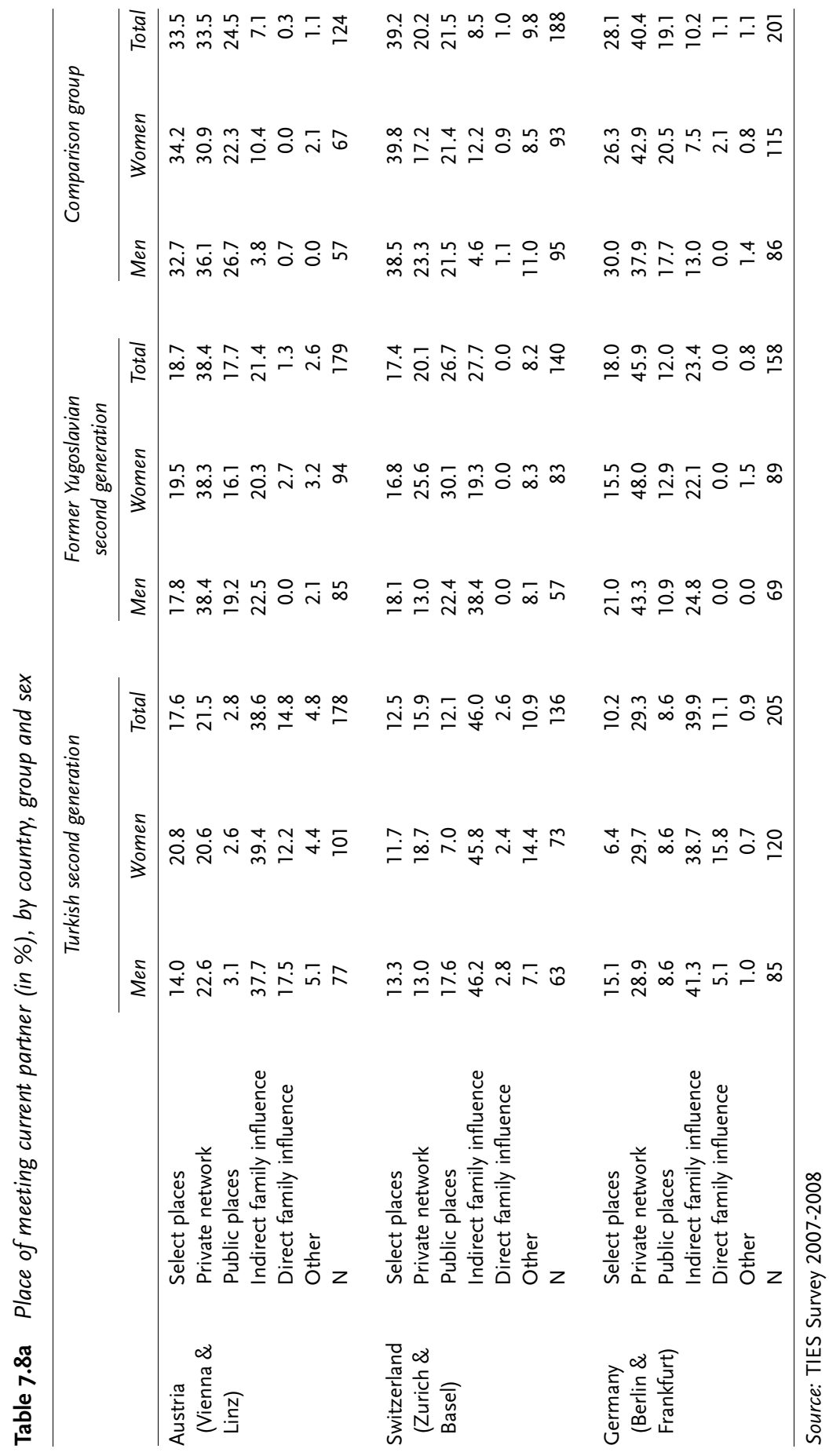




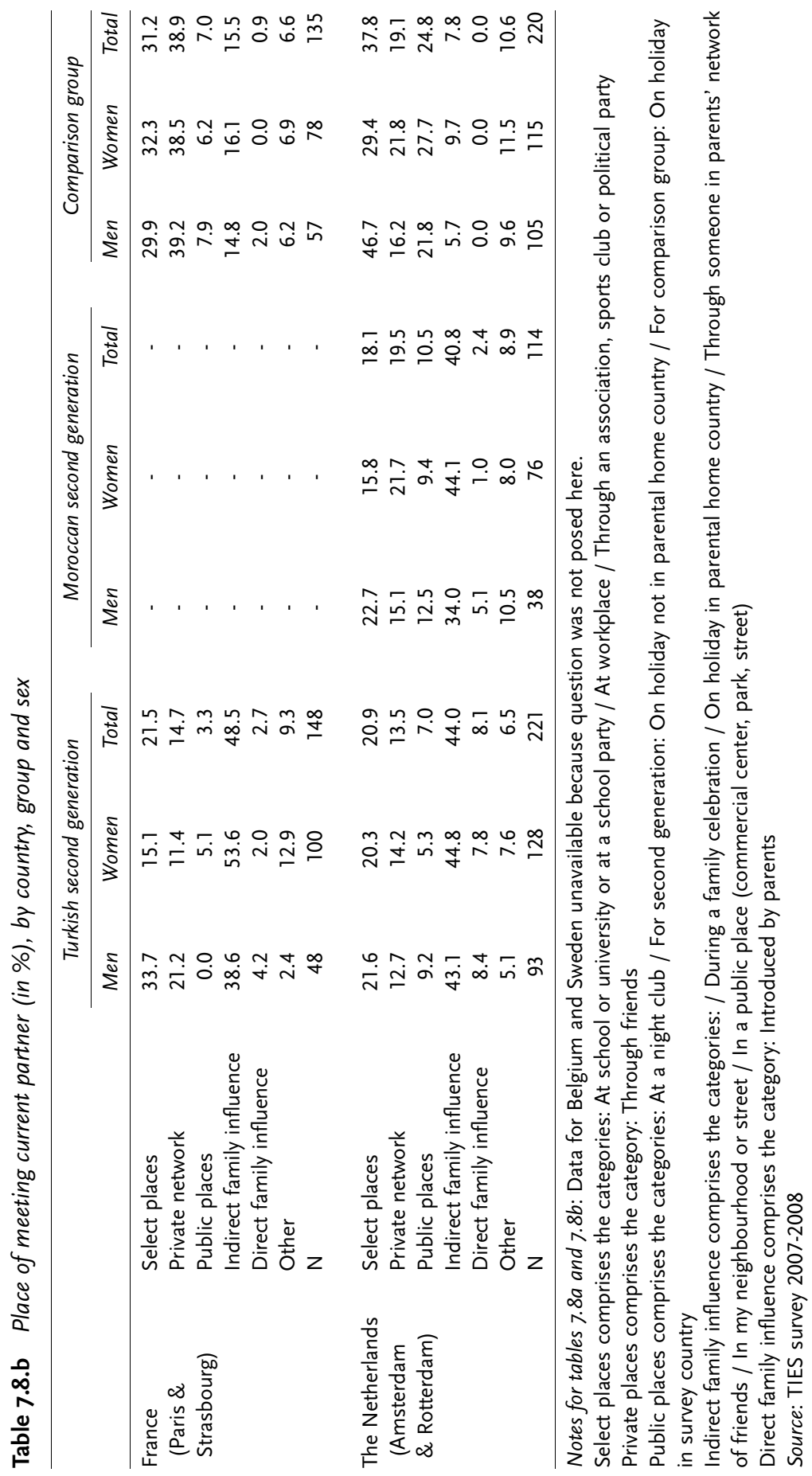


comparison group, except in Austria and Germany, where an indirect family influence plays a more significant role for women.

For second-generation Turks, friends are either the second- or third-most common way of meeting a partner. The most is at family gatherings, through family networks and while on holiday in Turkey - these three situations reflect an indirect family influence. The percentages for selfselective places (i.e. school, university and workplace) vary between 10 and 20 per cent, thus being two to three times less frequent than for the comparison groups. Direct parental influence is also visible in all countries. It is especially high in Austria for both sexes (17 per cent for men and 12 per cent for women); only for women in Germany (16 per cent versus 5 per cent for men); and slightly less important in the Netherlands (8 per cent for both sexes). In France, direct family influence is more frequent for men, but overall only of marginal importance ( 4 per cent for men and 2 per cent for women); the same applies to Switzerland (less than 3 per cent for both sexes).

In this regard, second-generation Moroccans prove quite similar to their Turkish peers. Partners are met primarily through the family network (44 per cent), although direct family intervention is less important ( 5 per cent for men and 1 per cent for women). Self-selective meeting places are reported far less often by second-generation Moroccans (18 per cent versus Turks' 38 per cent). By contrast, second-generation former Yugoslavians in Austrian, German and Swiss cities have very similar practices to those of the comparison group; this observation is particularly stable across countries.

In conclusion, we can account for the lower homogamy of Turkish and Moroccan second-generation couples observed earlier. This is partly the result of, by contrast, higher educational levels in the comparison groups and partly due to differences in the social network through which partners are found. If they are immigrants from Turkey or Morocco, the likelihood that they will have a different level of education than their second-generation partners increases notably, since school systems differ.

\section{The partner's migration background}

As noted earlier, the social and geographical space in which the offspring of immigrants meet their future partners is effectively transnational. Segregation, xenophobia and racism in the country of residence may restrict their pool of available partners from the majority population. The proportion of mixed couples in the parents' generation may also play an important role.

This section distinguishes three types of union: transnational unions formed with an immigrant born in the parents' country of origin (i.e. Turkey, Morocco or former Yugoslavia); mixed unions formed with someone born in the surveyed country whose parents were also born in the 
surveyed country; and unions formed with a person who is not only also of immigrant parentage but of the same origin. We will also examine to what extent the size of the community of origin influences the types of unions.

Regardless of country of residence, second-generation Turks have rarely formed couples with members of the majority population. Those doing so represent only 13 per cent in German cities, which is the highest rate of any country. The Swiss, Dutch and Belgian cities have the lowest proportion of mixed couples (3-6 per cent). Explanations for this considerably high level of endogamy are varied: examples include the strong influence exerted by parents; limits on the marriage market imposed by stigmatisation from the majority population (hence difficulty in finding a partner of non-immigrant background); religious boundaries that discourage unions with persons of another religious affiliation or none at all. Stringent boundaries do exist in European societies between groups of different religious affiliation, especially between Muslims and Christians (Alba \& Golden 1986; Kalmijn \& Van Tubergen 2007). At the same time, this is not surprising for the second generation; similar levels of endogamy can be found, for example, among descendants of Mexican and Chinese immigrants in Los Angeles (see Schneider, Chávez, Waters \& DeSipio forthcoming).

Most Turkish partners of our respondents are Turkish-born. This is the case for over 50 per cent in Sweden and Switzerland and even more than the 60-70 per cent found in the Austrian, French, Dutch and Belgian cities. Only the German outcomes constitute a remarkable exception to this pattern, since transnational couples in the two cities only represent 12 per cent of the couples. By contrast, 70 per cent chose a second-generation Turkish partner as opposed to 20-30 per cent in the other countries. Germany has the longest Turkish migration history and by far the largest Turkish community (Worbs 2003). For 2003, Worbs estimated a population of 1,322,500 adults of Turkish descent below age 35 in Germany. This makes the case unique: young adults of Turkish descent in Germany can choose potential partners from a much larger pool of second-generation peers with the same immigrant background than in the other countries. In this respect, marriage markets may function differently in the diverse countries (see also Huschek, De Valk \& Liefbroer 2010).

In relation to transnational marriages, a pronounced gender gap was observed in the Belgian, Austrian and French cities. Here second-generation Turkish women were more frequently in couples with a Turkish immigrant than were men (in Belgium, 80 per cent of women versus 66 per cent of men; in Austria, 68 per cent versus 55 per cent; in France, 70 per cent versus 36 per cent). This particularly large gender gap was not found in Sweden, Germany or Switzerland.

Second-generation Moroccans are seemingly subjected to the same processes as those of their Turkish counterparts. Their chosen partners were 


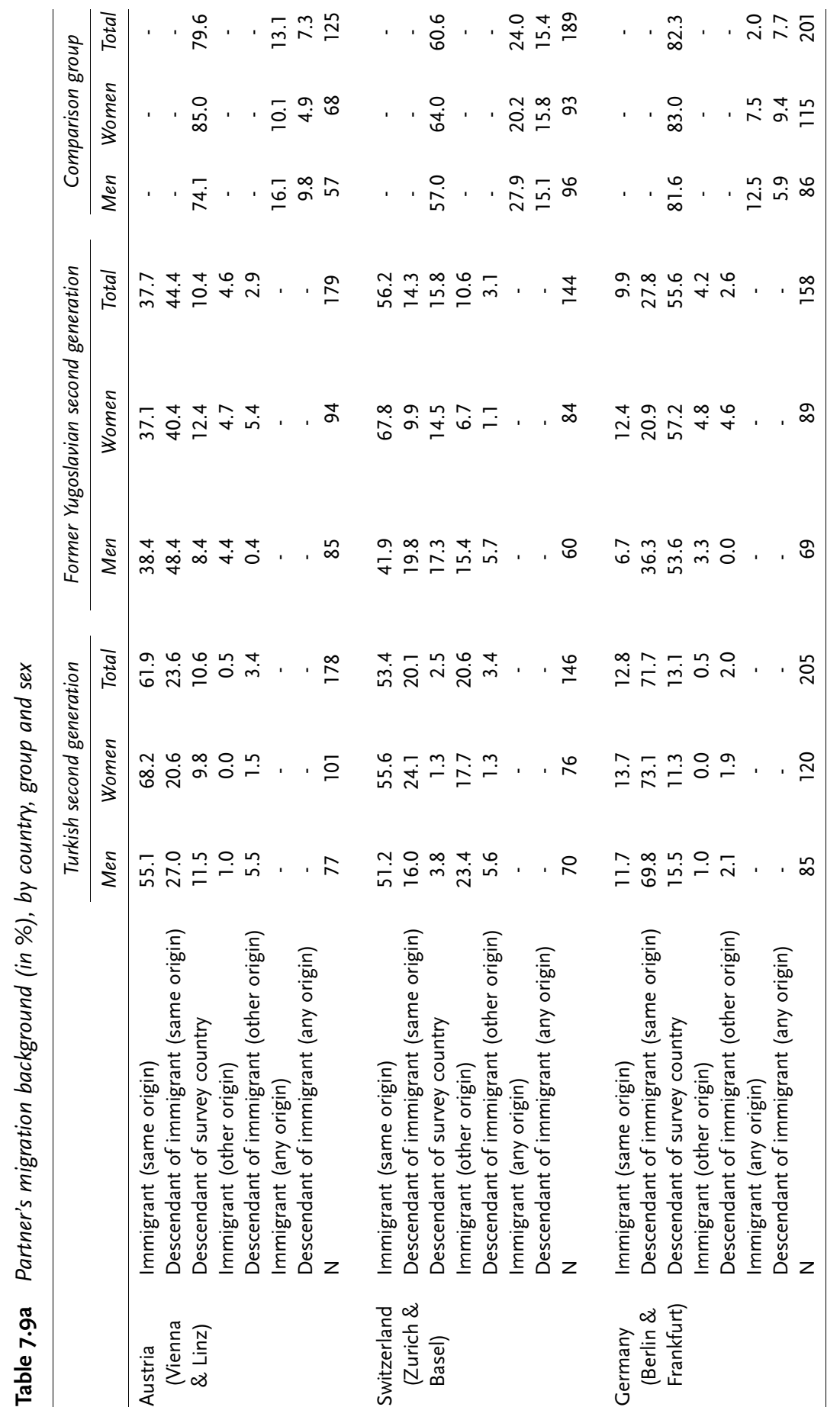




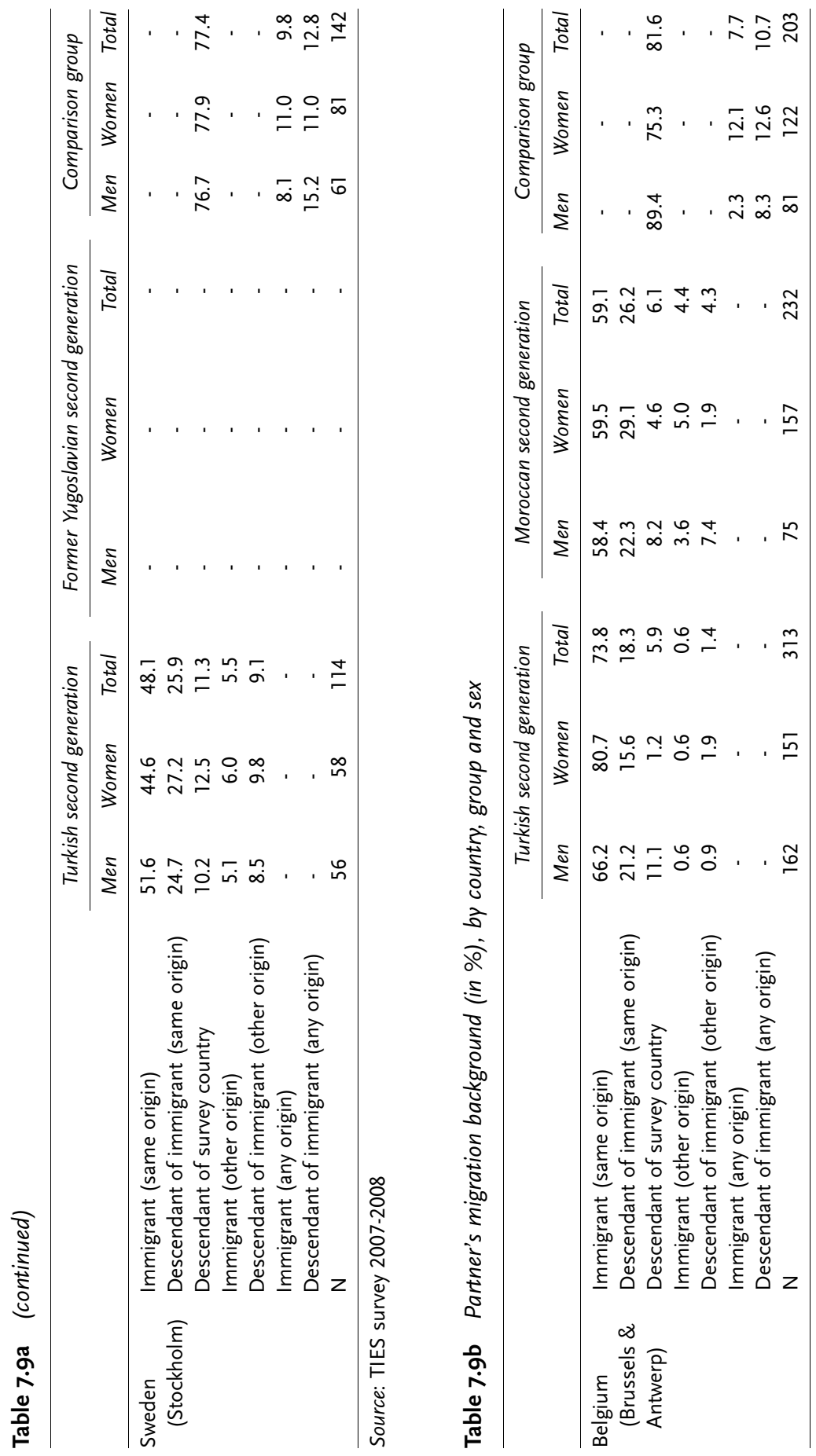




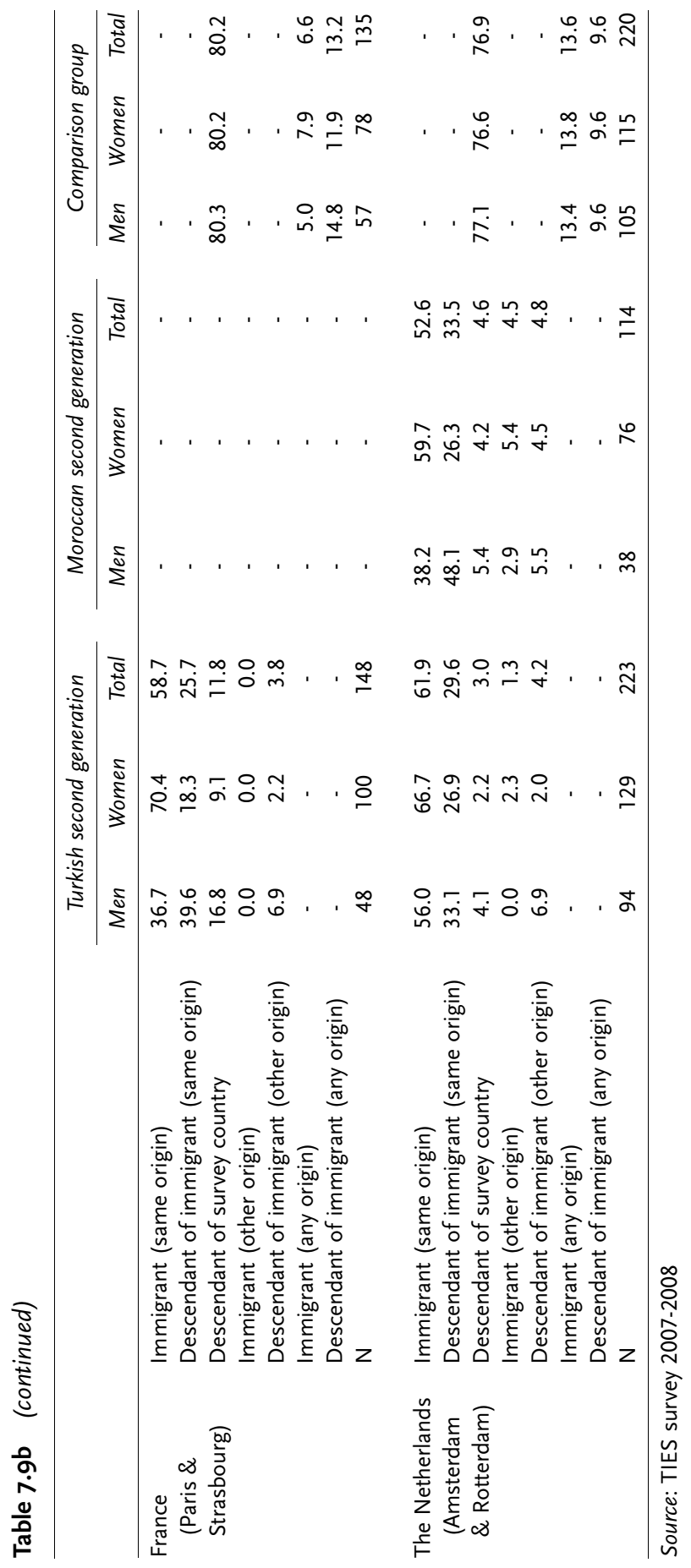


mainly Moroccan immigrants, a pattern again more marked for women than men. Second-generation former Yugoslavians present a more variegated picture, depending on their city of residence. In the Swiss and Austrian cities, half chose a partner born in former Yugoslavia (respectively, 56 per cent and 44 per cent), but in German cities the principal trend was to choose partners of native parentage (56 per cent).

\section{Transnational unions and educational homogamy}

This section examines whether the heterogamy of the couples can be linked to the partner's origin. Namely, do the immigrant partners have a higher or a lower educational level than the respondents? Tables 7.10a and $7.10 \mathrm{~b}$ present the educational level of the TIES respondents (I) compared with that of their partners $(\mathrm{P})$, according to their partners' origin.

When second-generation Turks partner with the majority population, they predominantly form educationally homogamous couples (50-60 per cent of the mixed couples). Between 12 and 20 per cent are more highly educated than their partners. Second-generation Turks rarely form a couple with someone from the majority population who is more highly educated. When the respondent is in a couple with a Turkish-born immigrant, the proportion of educationally homogamous couples becomes slightly lower (ranging from 36 per cent in Belgium to 56 per cent in the Netherlands). This means that more respondents live in heterogamous couples. In most cases, the respondent is less educated than the partner born in Turkey. This may signify that only the most highly educated people in Turkey are eligible candidates in the eyes of the second generation living in Europe, though it also can point to the fact that educational levels in Turkey are rising. Since all these couples live in Europe, it may also indicate that the European background of the respondent and the higher educational level of the Turkish partner create a sense of 'homogamy' for the couple. Secondgeneration Moroccans and former Yugoslavians seem to be subject to the same phenomenon.

\section{Transnational unions and opinions on sexuality}

Earlier in this chapter we hypothesised that certain union formation patterns, such as type of union and partner choice, are also connected to cultural values. The following section explores to what extent the norm of a woman's virginity at marriage is correlated with choice of a partner either from the survey country or from the parents' country of origin. As mentioned in the introduction to this chapter, this norm remains of importance in Turkey and Morocco.

Between a quarter and almost two thirds of second-generation Turkish respondents who live in couples consider women's engagement in 


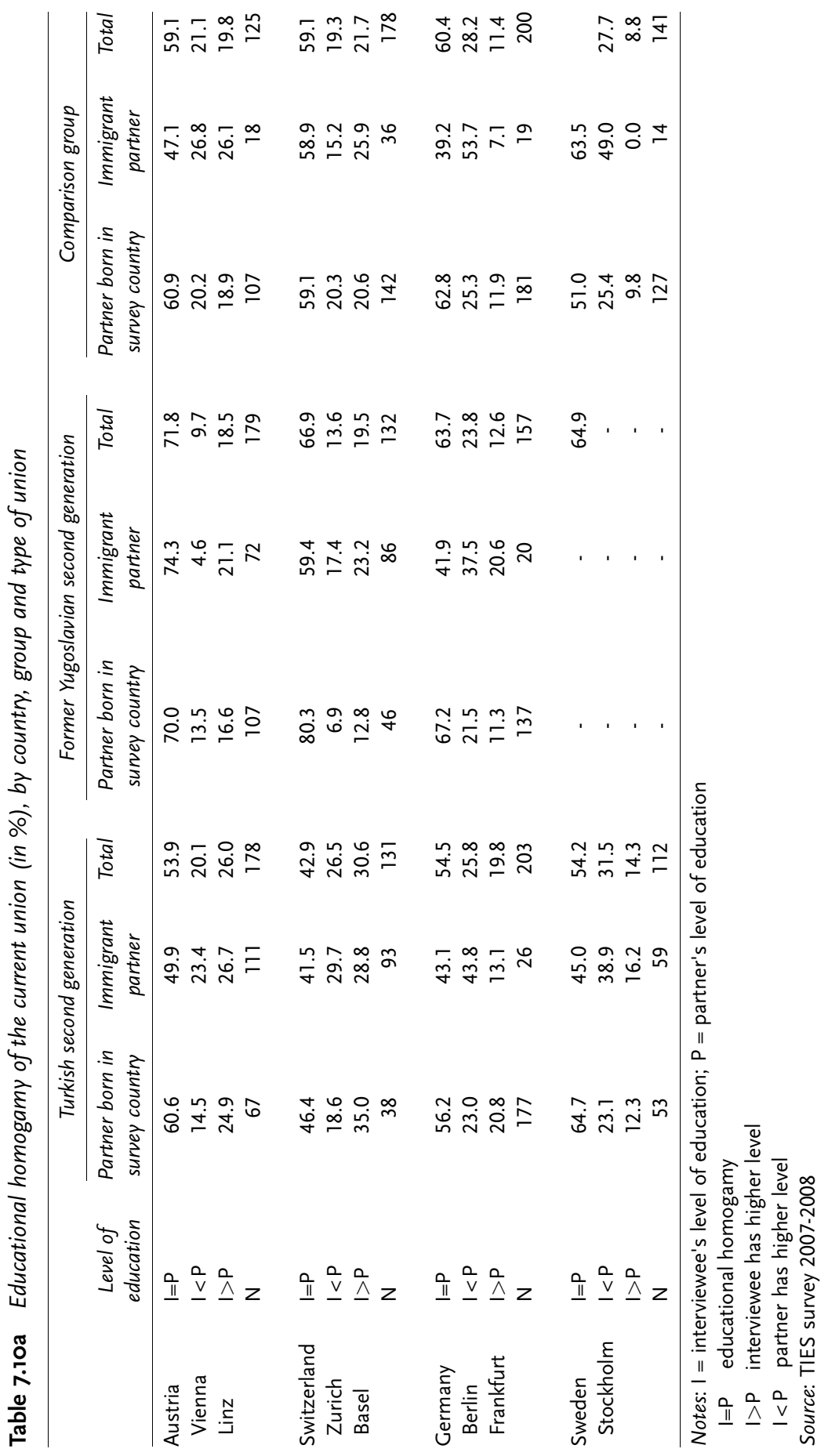




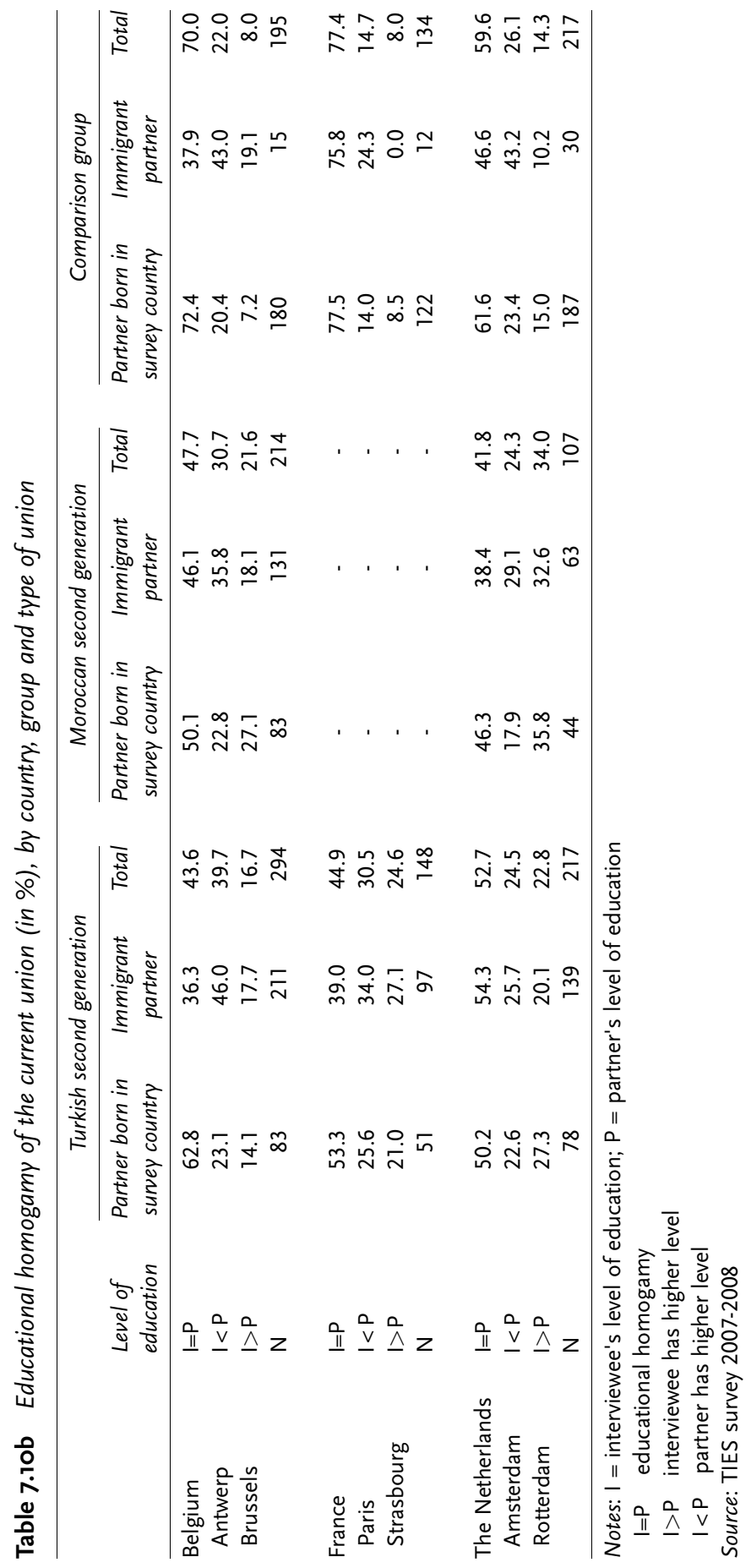




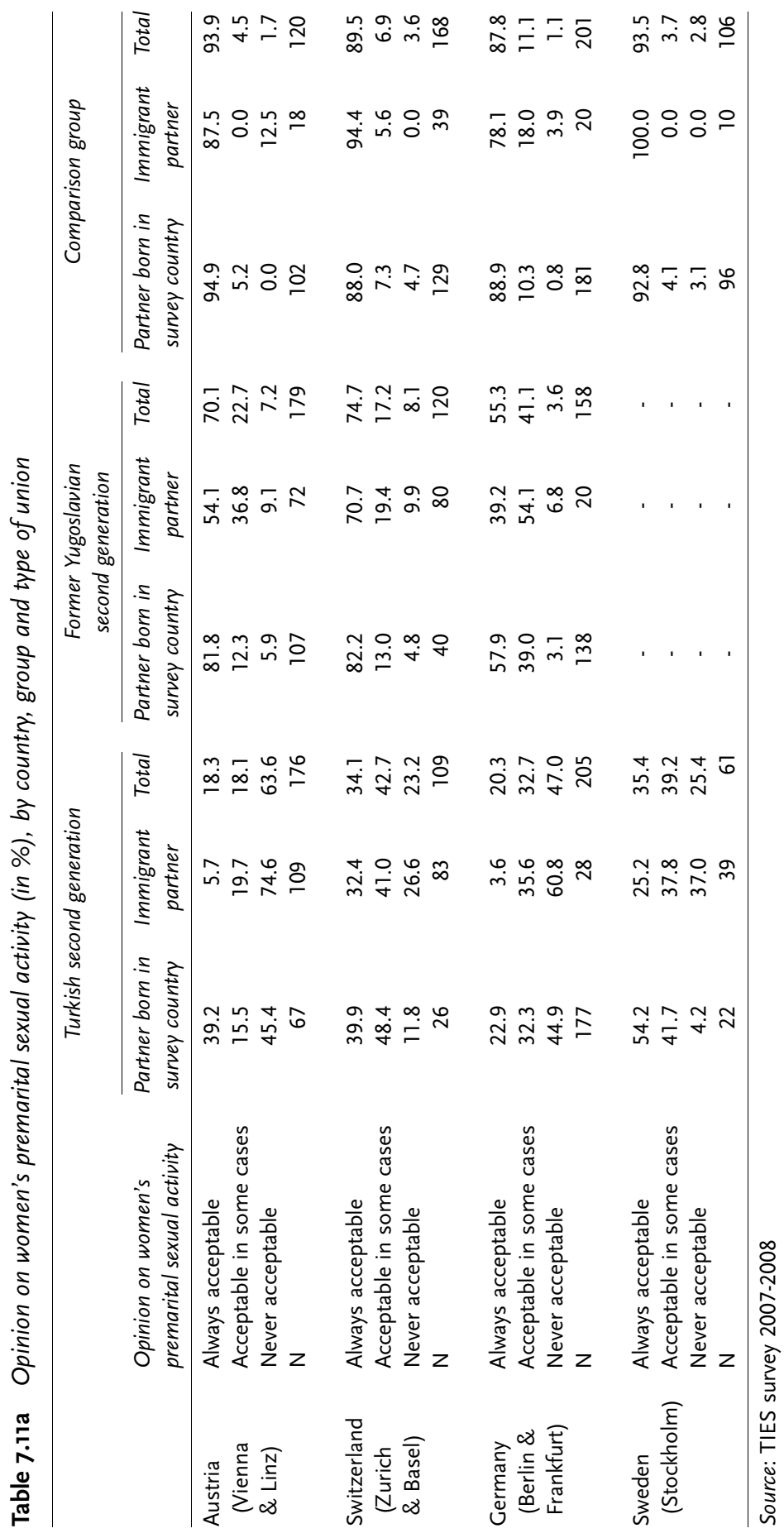




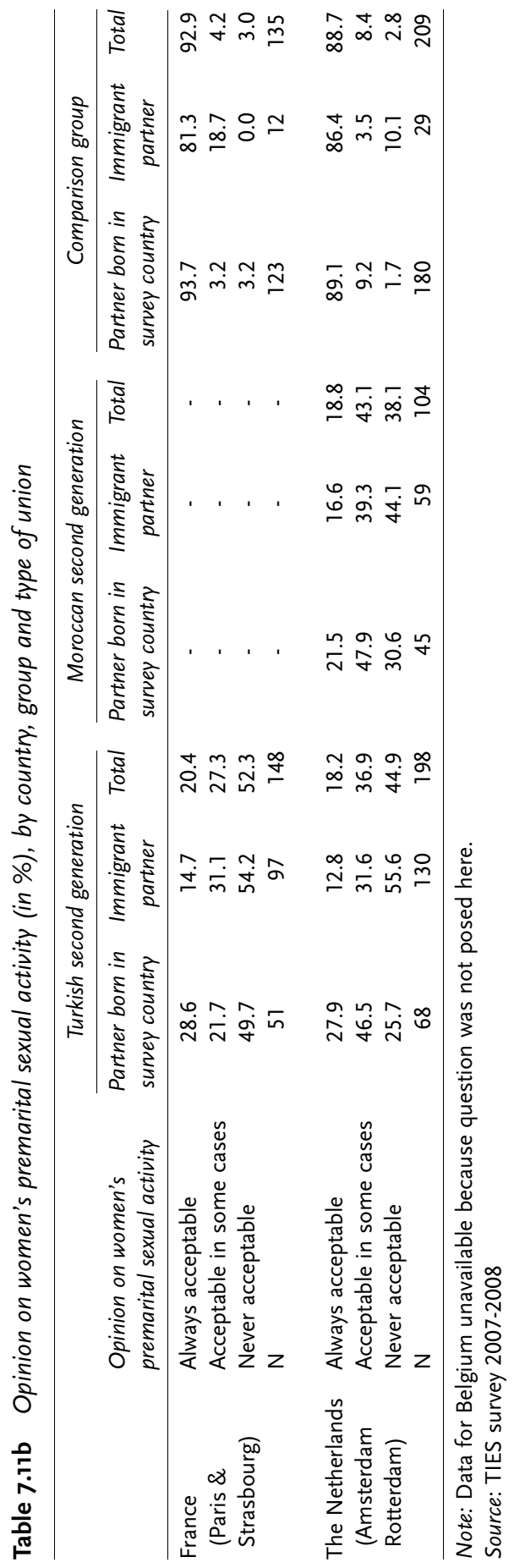


premarital sex as being 'never acceptable'. For those living in Switzerland or in Sweden, women's chastity is becoming a minority norm, though it is widely dominant in Austria and, albeit to a lesser extent, Germany. Young second-generation Moroccan men and women have similar opinions, while this position is endorsed by less than 4 per cent in the comparison groups. In keeping with previous indicators, young second-generation former Yugoslavian men and women come very close to the comparison groups.

In all cities, the share of those who attach a lot of importance to women's chastity is higher if the partner comes from Turkey. The causal relation between both items cannot be established here: it may as well be that the 'brightness' of boundaries between groups leads second-generation Turks to choose a partner in Turkey, also making them more likely to adhere to values and norms dominant in their partners' country of origin. At the same time, second-generation Turkish respondents may have chosen a partner from Turkey because they themselves adhere to these more traditional values, which they believe will have a stronger prevalence among possible partners there.

The German case is quite interesting in this regard since the rate of transnational unions is so much lower than in other countries. We would therefore expect the importance attached to female virginity to be lower, though it remains surprisingly high (45 per cent of second-generation Turks claim that women's engagement in premarital sexual activity is never acceptable). It is, however, much lower than in transnational couples (60 per cent). These findings indicate that views on sexuality are still highly influenced by the values of the immigrant parents or the wider Turkish diaspora, even when marrying a second-generation Turkish partner. Even though these findings reflect opinions and not practices - so there could well be a difference between what is expressed in public and what is experienced in private - we have reasons to believe any such disparity is small. $^{5}$

The data on sexual norms are particularly important to understand the meaning of both the timing and type of first union formation. Whereas the share of marriages does not significantly vary between cities, the opinions on female premarital sexual activity show remarkable variations. This may give some clues on how to interpret earlier-than-average union formation ages in Sweden and in Austria. In Sweden, this likely has to do with a correspondence to the belief in young adults' rights to autonomy and equal rights for women - also including among second-generation Turks. By contrast, Austria's seemingly similar outcome is probably best explained by just the opposite: a higher frequency of arranged marriages and widespread traditional ideas about gender roles in the Turkish community. 


\subsection{Conclusion}

The findings of this chapter can be summarised under three main headings. First, a strong common trend is observed among second-generation Turks living in Europe. Offspring of Turkish immigrants do not follow the dominant patterns of union formation in Turkey nor of the countries where they live. Overall, we may conclude that the transition to first union shows substantial variation between European countries, both for comparison groups and the second generation. Timing patterns between the different origin groups vary much more in some countries than in others. Sweden is the most extreme example, with a much sharper gender gap than origin variation concerning age at first union formation. Men and women behave differently, and these differences look exactly the same for second-generation Turks as the comparison group. For all the other countries except Germany, we may conclude that differences between men and women from the same origin group are generally more pronounced than those between origin groups.

Second-generation Turks form their first union later than people do in Turkey, though earlier than the comparison groups in their countries of residence. We also found that marriage is no longer universal, but remains much more common than cohabitation. Women's virginity before marriage remains widespread, but it is no longer a necessarily dominant norm. The second-generation - women especially - often chooses a partner born in Turkey (except in Germany, where they more often choose a fellow second-generation partner) and, when they do so, it is likely for the partner to be more highly educated than they are. Demographically, this is not really surprising. However, it contradicts a commonplace image in political discourse and the media of Turks 'importing' low-educated brides and grooms from the Turkish countryside.

Choosing a spouse born in Turkey is a key issue, especially for women. This holds for all countries except Germany, where it is more common to choose a partner from among local second-generation Turks. Yet interestingly, our analyses on partner characteristics revealed that young secondgeneration Turkish adults who find partners in Turkey are particularly wont to find partners who are more highly educated than themselves. Although this is not really surprising given that women generally marry men who are slightly older and more highly educated, it also contradicts the aforementioned stereotype of 'importing' a low-educated spouse.

It is important to recognise that the national contexts specific to the survey countries also show their effects. In each country, a minority within the Turkish second generation follows the national patterns. This minority is larger in some countries than others, primarily dependent on institutional arrangements, economic situation and a social climate that favour female autonomy and equal participation. This minority is particularly sizeable in Sweden and Switzerland, but smaller in Austria, Belgium and Germany. 
Let it be noted that at the time of the survey the second generation was still relatively young and many respondents had yet to enter partnerships for the first time. In the years to come, this group who had postponed union formation may in fact be making partner choices more similar to that of their comparison groups peers. How these young adults negotiate their life course choices in private and in the public spheres of education and the labour market will be crucial to their own personal development and that of European societies at large.

\section{Notes}

I Unlike other countries, France showed a difference between cities (Milewski \& Hamel 20I0). For second-generation Turks and their comparison group peers, first union formation occurred later in Paris than in Strasbourg. This reflects a difference in the composition of the surveyed population: Paris attracts more highly educated persons, both immigrants and nationals, who tend to form couples later on. In addition, access to housing is especially difficult in the capital city, where rents are particularly high.

2 As in France, a difference is observed between the two cities, with first union formation occurring later in Berlin than in Frankfurt. The more difficult-to-access labour market in the European capitals, as compared to the secondary cities, may account for this (see chapter 6).

3 Our additional analyses (not shown) revealed that city differences play only a minor role in female union formation behaviour.

4 In several European countries, women now have higher levels of educational attainment than men, though they do not systematically get better jobs. Discrimination when it comes to accessing employment and notably in their actual professional careers keeps them in less well-paid, less prestigious work for which they are overqualified to begin with. Since men are generally more highly positioned than women on the labour market and vis-à-vis social stratification, they tend to form couples with women in lower positions. As a result, a man may form a couple with a woman who holds the same socio-economic status as himself though is nonetheless better qualified on the job market. Information about the jobs partners held when they first met is not included in the TIES survey, so we cannot detail this phenomenon further.

5 The TIES survey asked respondents to specify their age upon first engaging in sexual intercourse. The results indicate a strong correlation between respondents' opinions on sexual issues and their reported practices (Milewski \& Hamel 20I0).

\section{References}

Alba, R. \& R. Golden (1986), 'Patterns of ethnic marriage in the United States', Social Forces 65: 202-223.

Anil, E. (2005), Turkish Civil and Penal Code Reforms from a Gender Perspective: The Success of Two Nationwide Campaigns. Istanbul: Women for Women's Human Rights New Ways.

Atkinson, A. \& E. Marlier (2010), Income and Living Conditions in Europe. Luxembourg: Eurostat. 
Bernhardt, E., F. Goldscheider, C. Goldscheider \& G. Bjeren (2007), Immigration, Gender and Family Transitions to Adulthood in Sweden. Lanham: University Press of America.

Billari, F. (2005), 'Partnership, childbearing and parenting: Trends of the 1990s', in M. Macura, A. L. MacDonald \& W. Haug (eds.), The New Demographic Regime: Population Challenges and Policy Responses, 63-94. New York/Geneva: United Nations.

Billari, F. \& C. Wilson (2001), 'Convergence towards diversity? Cohort dynamics in the transition to adulthood in contemporary Western Europe’, working paper 2001-039. http:// www.demogr.mpg.de/Papers/Working/wp-2001-039.pdf.

Bozon, M. \& F. Héran (1989), 'Finding a spouse: A survey on how French couples meet', Population: An English Selection 1: 91-121.

Corijn, M. (2001), 'Transition to adulthood in France', in M. Corijn \& E. Klijzing (eds.), Transitions to Adulthood in Europe. European Studies of Population, vol. 10: 131-151, Dordrecht/Boston/London: Kluwer Academic Publishers.

De Valk, H.A.G. \& A.C. Liefbroer (2007), 'Timing preferences for women's family-life transitions: Intergenerational transmission among migrants and Dutch', Journal of Marriage and Family 69: 190-206.

Elzinga, C.H. \& A.C. Liefbroer (2007), 'De-standardization of family-life trajectories of young adults: A cross-national comparison using sequence analysis', European Journal of Population 23 (3/4): 225-250.

Girard, A. (1964), Le choix du conjoint: Une enquête psycho-sociologique en France. Paris: Presses Universitaires de France.

Gordon, M.M. (1964), Assimilation in American Life. New York: Oxford University Press.

Hacettepe University Institute of Population Studies (HUIPS) (2004), Turkey: Demographic and Health Survey. Ankara: HUIPS. http://www.measuredhs.com.

Hullen, G. (2001), 'Transition to adulthood in Germany', in M. Corijn \& E. Klijzing (eds.), Transitions to Adulthood in Europe. European Studies of Population, vol. 10: 153-169. Dordrecht/Boston/London: Kluwer Academic Publishers.

Huschek, D., H.A.G. de Valk \& A.C. Liefbroer (2010), 'Patterns of partner choice between preferences \& structural constraints: The case of the Turkish second generation in Europe', presentation at the ISA World Conference, Gothenburg, 15 July 2010.

Ilkkaracan, P. (2007), Reforming the Penal Code in Turkey: The Campaign for the Reform of the Turkish Penal Code from a Gender Perspective. http://www.ids.ac.uk/ids/Part/proj/ pnp.html.

Kalmijn, M. (2007), 'Explaining cross-national differences in marriage, cohabitation, and divorce in Europe, 1990-2000', Population Studies 61 (3): 243-263.

Kalmijn, M. (1998), 'Intermarriage and homogamy: Causes, patterns, trends', Annual Review of Sociology 24: 395-421.

Kalmijn, M. (1994), 'Mating by cultural and economic occupational status', The American Journal of Sociology 100 (2): 422-452.

Kalmijn, M. (1991), 'Status homogamy in the United States', The American Journal of Sociology 97(2): 496-523.

Kalmijn, M. \& H. Flap (2001), 'Assortative mating: Unintended consequences of organized settings for partner choice’, Social Forces 79: 1289-1312.

Kalmijn, M. \& F. van Tubergen (2007), 'Ethnic intermarriage in the Netherlands: Confirmations and refutations of accepted insights', European Journal of Population 22: 371-397.

Lampard, R. (2007), 'Couples' places of meeting in late 20th century Britain: Class, continuity and change', European Sociological Review 23 (3): 357-371.

Lesthaeghe, R. (ed.), (2000), Communities and Generations: Turkish and Moroccan Populations in Belgium. The Hague: NIDI CBGS Publications. 
Lesthaeghe, R. \& D. van de Kaa (1986), 'Twee demografische transities?', in R. Lesthaeghe \& D. van de Kaa (eds.), Bevolking: Groei en krimp. Mens \& Maatschappij, 9-42. Deventer: Van Loghum Slaterus.

Liefbroer, A.C. \& F.K. Goldscheider (2006), 'Transitions to adulthood: How unique is Sweden in the European context?', in E.M. Bernhardt, C. Goldscheider, F. Goldscheider \& G. Bjerén (eds.), 203-227. Immigration, Gender and Family Transitions to Adulthood in Sweden. Lanham: University Press of America.

Locoh, T. \& Z. Ouadah-Bedidi (2010), 'Las familias y las relaciones de género en el Magreb', in S. Bessis \& G. Martin Muñoz (eds.), 11-44, Mujer y familia en las sociedades árabes actuales. Barcelona: Editions Bellaterra.

Loudghiri, K. (2003), 'Nuptialité et exposition aux risques de grossesse, in Ministère de la Santé, ORC Macro, et Ligue des États Arabes', Enquête sur la population et la santé familiale, 83-92.

Milewski, N. \& C. Hamel (2010), 'Union formation and partner choice in a transnational context: The case of descendants of Turkish immigrants in France', International Migration Review 44 (3): 615-658.

Muttarak, R. (2003), 'Who intermarries in Britain? Ethnic intermarriage', $\mathrm{PhD}$ dissertation, University of Oxford.

Naamane-Guessous, S. (1985), Au-delà de toute pudeur: La sexualité féminine au Maroc: Conclusion d'une enquête sociologique menée de 1981 à 1984 à Casablanca. Casablanca: Eddif.

Ouadah-Bedidi, Z. \& J. Vallin (2000), 'Maghreb: La chute irrésistible de la fécondité', Population and Sociétés 359: 1-4.

Ozyegin, G. (2009), 'Virginal facades', The European Journal of Women's Studies 16 (2): $103-123$.

Parla, A. (2001), 'The "honor" of the state: Virginity examinations in Turkey', Feminist Studies 27 (1): 65-88.

Peristiany, J.G. (ed.) (1965), Honour and Shame: The Values of Mediterranean Society. Athens: Weidenfeld \& Nicolson (in association with the Social Sciences Centre).

Perlman, J. \& M. Waters (2004), 'Intermarriage then and now: Race, generation and the changing meaning of marriage', in N. Foner \& G. Fredrickson (eds.), Not Just Black and White: Historical and Contemporary Perspectives on Immigration, Race and Ethnicity in the United States, 262-277. New York: Russell Sage Foundation.

Pfeifer C. \& V. Nowak (2001), 'Transition to adulthood in Austria', in M. Corijn \& E. Klijzing (eds.) Transitions to Adulthood in Europe: European Studies of Population, vol. 10, 43-66. Dordrecht/Boston/London: Kluwer Academic Publishers.

Philipov, D. \& J. Dorbritz. (2003), 'Demographic consequences of economic transition in countries of central and eastern Europe', Population Studies 39. Strasbourg: Council of Europe Publishing.

Prioux, F. (2006), 'Cohabitation, marriage and separation: Contrasts in Europe', Population and Society 422: 1-4.

Sobotka, T. \& L. Toulemon (2008), 'Changing family and partnership behaviour: Common trends and persistent diversity across Europe', Demographic Research 19 (6): 85-138.

Safi, M. (2008), 'Intermarriage and assimilation: Disparities in levels of exogamy among immigrants in France', Population 63 (2): 239-268.

Schneider, J., L. Chávez, M. Waters \& L. DeSipio (2012): 'Second generation belonging: A contextualization of "here" and "there", in M. Crul \& J. Mollenkopf (eds.), The Changing Face of World Cities: The Second Generation in Europe and the United States. New York: Russell Sage Foundation.

Song, M. (2009), 'Is intermarriage a good indicator of integration?' Journal of Ethnic and Migration Studies 35 (2): 331-348. 
Thomsin, L., J.-M. Le Goff \& C. Sauvain-Dugerdil (2004), 'Genre et étapes du passage à la vie adulte en Suisse', Espace Populations Sociétés 1: 81-96.

Thornton, A. \& D. Philipov (2009), 'Sweeping changes in marriage, cohabitation, and childbearing in Central and Eastern Europe: New insights from the developmental idealism framework', European Journal of Population 25 (2): 123-156.

Timmerman, C., I. Lodewyckx \& J. Wets (2009), 'Marriage at the intersection between tradition and globalization: Turkish marriage migration between Emirdag and Belgium from 1989 to present', History of the Family 14 (2): 232-244.

Ultee, W.C. \& R. Luijkx (1990), 'Educational heterogamy and father to son occupational mobility in 23 industrial nations: General societal openness or compensatory strategies of reproduction?', European Sociological Review 6: 125-149.

Uunk, W.J.G. (1996), 'Who marries whom? The roles of social origins, education and high culture in mate selection of industrial societies during the twentieth century', PhD dissertation. Nijmegen University.

Van de Velde, C. (2008a), Devenir adulte: Sociologie comparée de la jeunesse en Europe. Paris: Presses Universitaires de France.

Van de Velde, C. (2008b), 'L'autonomie des jeunes adultes, une affaire d'État? Des politiques publiques aux cultures familiales en Europe', Informations Sociales: 'L'individu et ses appartenances' 145: 112-121.

Worbs, S. (2003), 'The second generation in Germany: Between school and labor market', International Migration Review 37 (4): 1011-1038.

World Economic Forum (2010), 'Global gender gap'. Available at http://www.weforum.org/ en/initiatives/gcp/Gender\%20Gap/index.htm.

Zoglin, K. (2009), 'Morocco's Family Code: Improving equality for women', Human Rights Quarterly 31 (4): 964-984. 


\section{Appendix}

Figure 7.4 Transition to a first union of second-generation Moroccans
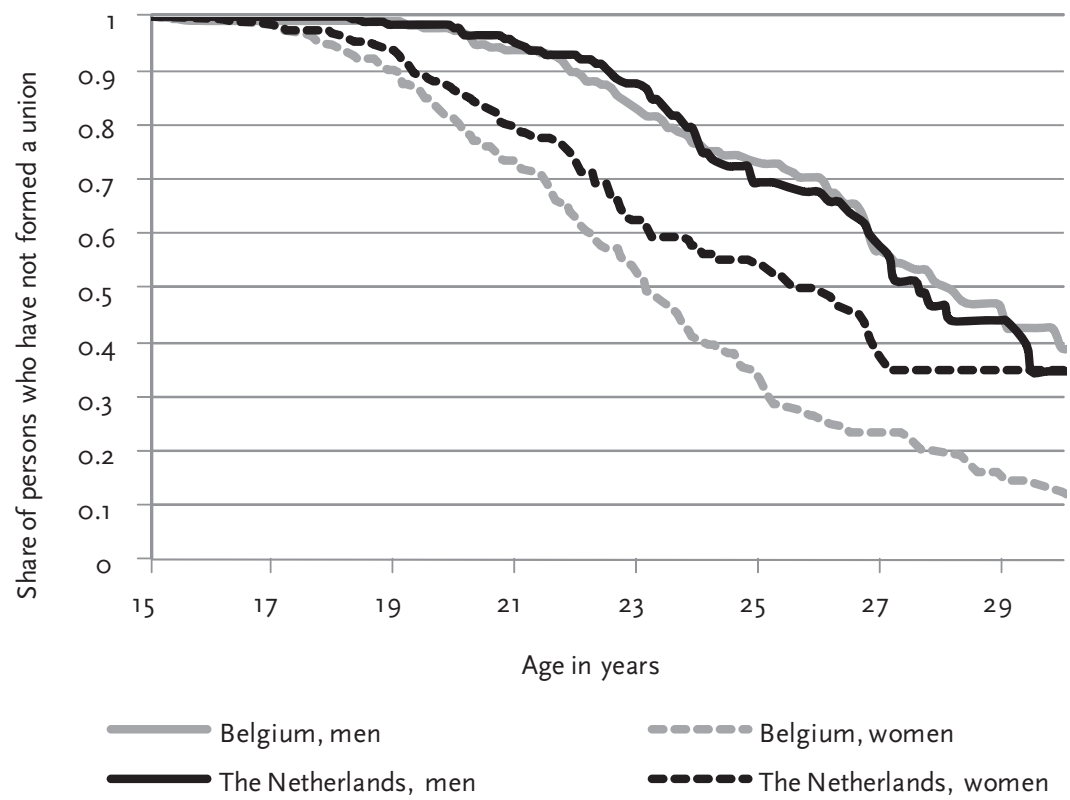

Source: TIES survey $2007-2008$ 
Figure 7.5 Transition to a first union of second-generation former-Yugoslavians

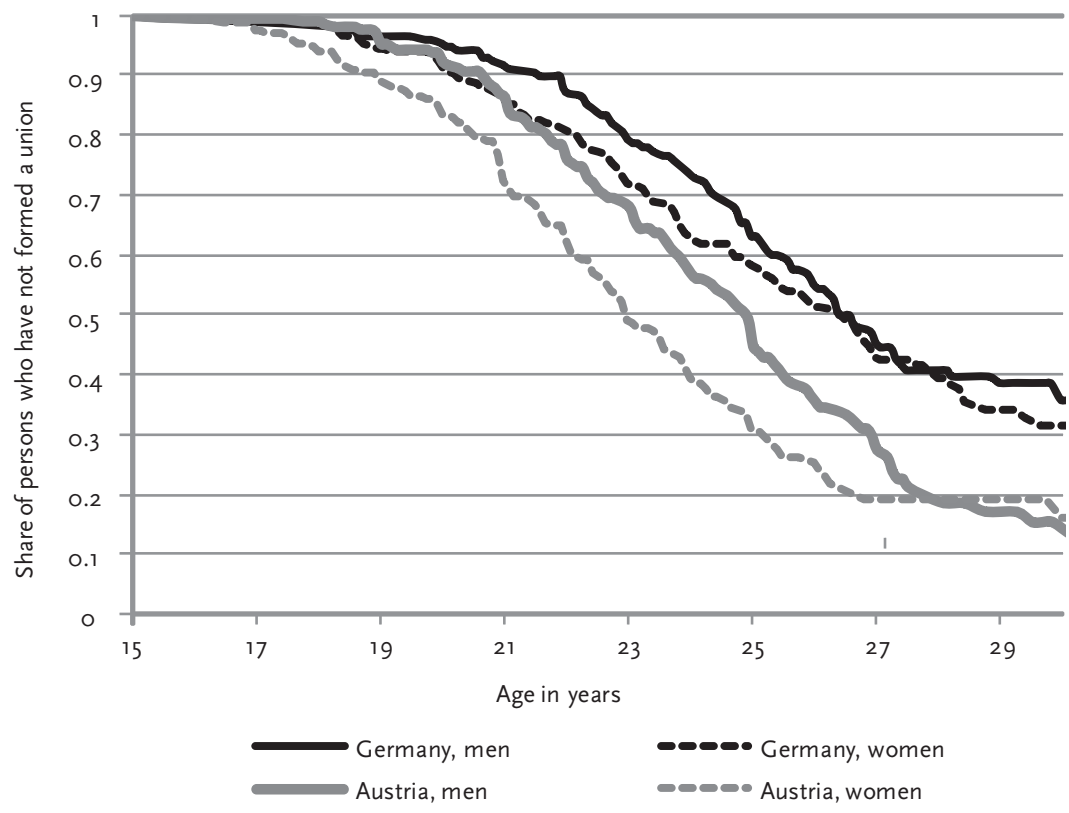

Source: TIES survey $2007-2008$ 
Figure 7.6a Transition to first union in Belgium

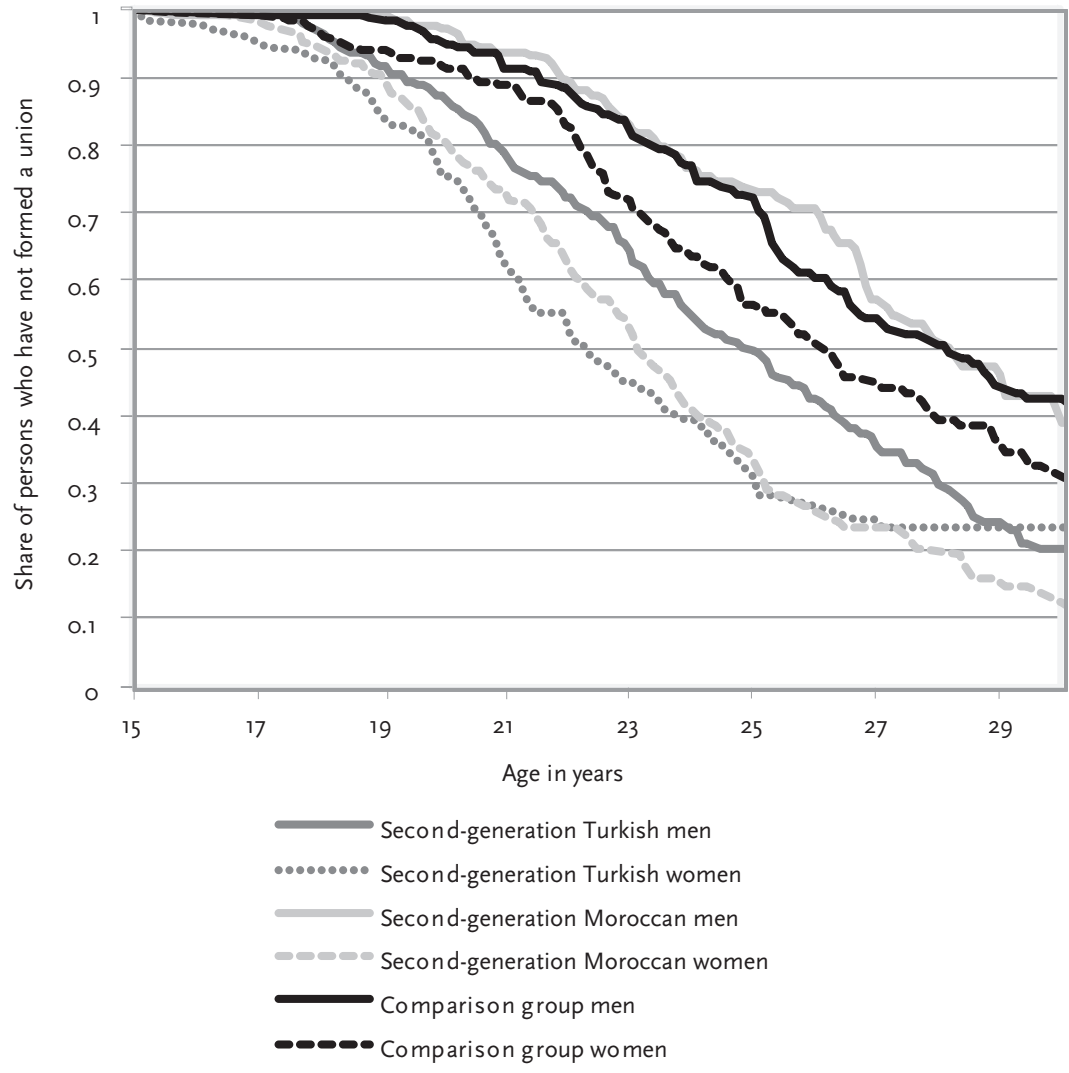

Source: TIES survey $2007-2008$ 
Figure 7.6b Transition to first union in the Netherlands

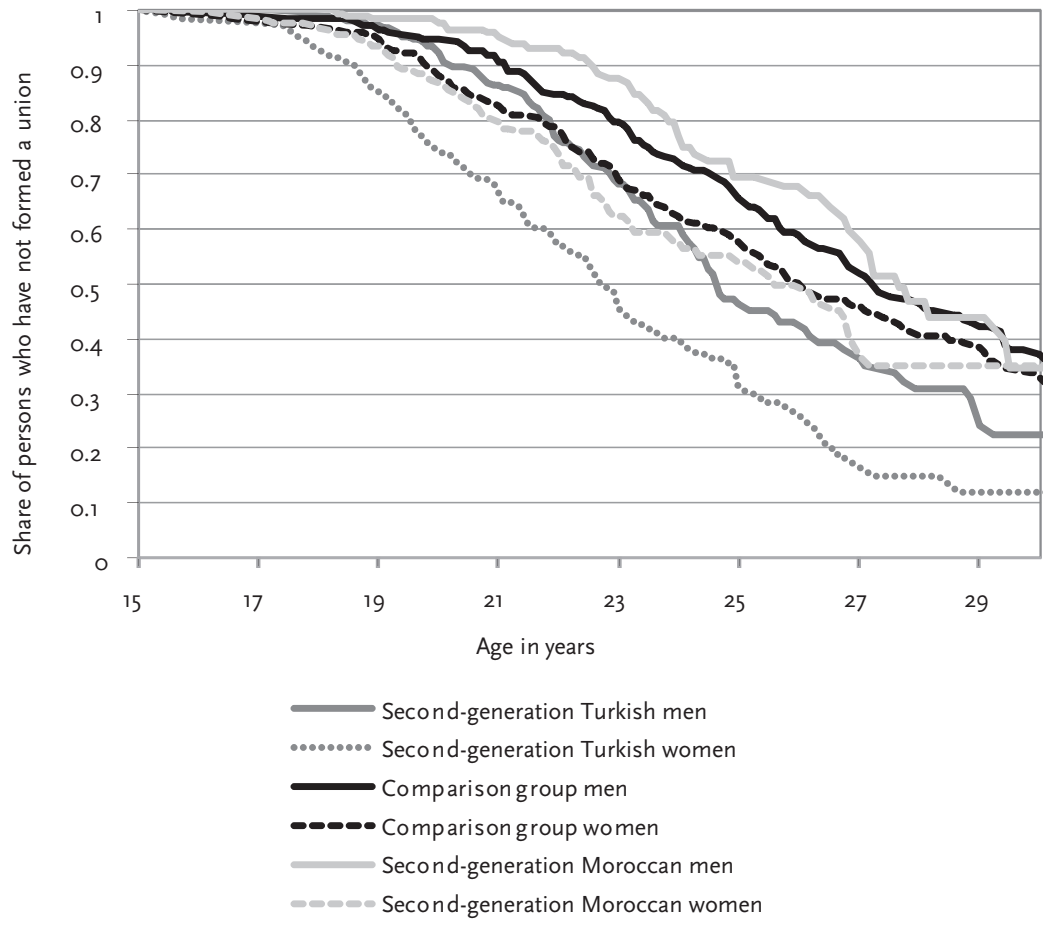

Source: TIES survey $2007-2008$ 
Table 7.12a Relative risks in transition to a first union for Moroccan and former Yugoslavian second-generation men

\begin{tabular}{|c|c|c|c|c|c|}
\hline \multirow[b]{2}{*}{ Variable } & \multicolumn{2}{|c|}{ Turkish second generation } & \multicolumn{3}{|c|}{ Comparison groups } \\
\hline & Model 1 & Model 2 & Model 1 & Model & \\
\hline Sweden & 1 & 1 & 1 & 1 & \\
\hline France & $0.66 *$ & 0.67 & $0.70 *$ & 0.81 & \\
\hline The Netherlands & 1.00 & 0.92 & $0.69 * *$ & 0.79 & \\
\hline Germany & 0.76 & $0.52 * *$ & $0.53 * * *$ & 0.58 & $* *$ \\
\hline Austria & $1.37 *$ & 1.13 & $0.67 *$ & 0.73 & \\
\hline Switzerland & 0.79 & 0.81 & $0.58 * * *$ & 0.65 & $*$ \\
\hline Belgium & 1.12 & 0.91 & $0.56 * * *$ & 0.58 & $* * *$ \\
\hline
\end{tabular}

Birth cohort

1971-1980

$1981-1990$

$\begin{array}{rr}1 & 1 \\ 0.8 & 0.80\end{array}$

Education

Primary/special education

0.78

0.78

Lower secondary

Apprenticeship

Upper secondary/apprenticeship

0.80

0.80

Tertiary

$0.65 * *$

$0.65 * *$

Enrolment in education

$0.32 * * *$

$0.32 * * *$

Religion during childhood

Muslim

1

0.90

n.a.

None, Jewish or other

0.83

0.96

Number of siblings

0

1 or 2

1

1

1.22

1.22

$3+$

1.50

1.50

Father's education

Primary or less

$\begin{array}{lr}1 & 1 \\ 086 & 086\end{array}$

Secondary

0.86

0.86

Tertiary

0.83

0.83

Missing

1.44

1.44

Age in years

$<20$

0.002 䗋

0.002 w

$0.002 * * *$

$0.003 *$

20-25

$0.009 * \cdots *$

$0.011 * * *$

$0.008 * \cdots *$

0.018 * $* x *$

25-30

0.014 䗋

0.017 *⿰冫欠

0.014 *⿻一从火

0.032 knt

$30+$

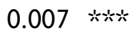

$0.009 * * *$

0.011 w

0.023 为炏

Log likelihood

$-1018.1$

$-916.5$

$-1087.5 \quad-1008.9$

$*=5 \% ; * *=1 \% ; * * *=0.1 \%$.

Notes: Education variables each contain a small number of missing values without significant impact (not displayed here).

Education of respondent is a time-varying covariate.

Source: TIES survey 2007-2008 
Table 7.12b Relative risks in transition to a first union for comparison group and Turkish second-generation women

\begin{tabular}{|c|c|c|c|c|c|}
\hline \multirow[b]{2}{*}{ Variable } & \multicolumn{2}{|c|}{$\begin{array}{c}\text { Second-generation Moroccan } \\
\text { women }\end{array}$} & \multicolumn{3}{|c|}{$\begin{array}{l}\text { Second-generation former } \\
\text { Yugoslavian women }\end{array}$} \\
\hline & Model 1 & Model 2 & Variable & Model 1 & Model 2 \\
\hline The Netherlands & 1 & 1 & Germany & 1 & 1 \\
\hline Belgium & $1.63 * * *$ & $1.76 * * *$ & Austria & $1.86 * * * *$ & $1.81 * *$ \\
\hline
\end{tabular}

Birth cohort

1971-1980

1

$0.8 * *$

1.15

0.45

Primary school/

special education

Lower secondary

Apprenticeship

Upper secondary/

apprenticeship

Tertiary

Enrolment in education

Religion during

childhood

Muslim

None or other

Christian

Number of siblings

0

1 or 2

$3+$

Father's education

Primary or less

Secondary

Tertiary

Age in years

18-20

20-25

25-30

30-35

Log likelihood

\section{(15}

$0.46 * *$

$0.44 *$

$0.11 * * * *$

0.11 蜘火

0.95

1

1.15

0.65

1.0

1.68 *

$0.46 * *$

$0.16 *$ w

$0.47 *$

(


Table 7.12c Relative risks in transition to a first union for men

\begin{tabular}{|c|c|c|c|c|c|c|c|c|c|}
\hline \multirow[b]{2}{*}{ Variable } & \multicolumn{4}{|c|}{$\begin{array}{l}\text { Moroccan second } \\
\text { generation }\end{array}$} & \multicolumn{5}{|c|}{$\begin{array}{l}\text { Former Yugoslavian } \\
\text { second generation }\end{array}$} \\
\hline & \multicolumn{2}{|c|}{ Model 1} & \multicolumn{2}{|c|}{ Model 2} & Variable & \multicolumn{2}{|c|}{ Model 1} & \multicolumn{2}{|c|}{ Model 2} \\
\hline The Netherlands & 1 & & 1 & & Germany & 1 & & 1 & \\
\hline Belgium & 1.00 & & 0.84 & & Austria & 1.69 & $* *$ & 1.69 & $* *$ \\
\hline \multicolumn{10}{|l|}{ Birth cohort } \\
\hline 1971-80 & & & 1 & & & & & 1 & \\
\hline 1981-90 & & & 0.7 & & & & & 0.9 & \\
\hline \multicolumn{10}{|l|}{ Education } \\
\hline $\begin{array}{l}\text { Primary/special } \\
\text { education }\end{array}$ & & & 1.51 & & & & & 0.50 & \\
\hline Lower secondary & & & 1 & & & & & 1 & \\
\hline Apprenticeship & & & 1.46 & & & & & 0.67 & \\
\hline $\begin{array}{l}\text { Upper secondary/ } \\
\text { apprenticeship }\end{array}$ & & & 1.18 & & & & & 0.55 & \\
\hline Tertiary & & & 1.22 & & & & & 0.66 & \\
\hline Enrolment in education & & & 1.31 & & & & & 0.28 & $* *$ \\
\hline \multicolumn{10}{|l|}{$\begin{array}{l}\text { Religion during } \\
\text { childhood }\end{array}$} \\
\hline Muslim & & & 1.31 & & & & & 1 & \\
\hline None or other & & & 1 & & & & & 1.12 & \\
\hline Christian & & & n.a. & & & & & 1.18 & \\
\hline \multicolumn{10}{|l|}{ Number of siblings } \\
\hline 0 & & & 1 & & & & & 1 & \\
\hline 1 or 2 & & & 0.76 & & & & & 1.83 & $* *$ \\
\hline $3+$ & & & 1.17 & & & & & 2.36 & $* *$ \\
\hline \multicolumn{10}{|l|}{ Father's education } \\
\hline Primary or less & & & 1 & & & & & 1 & \\
\hline Secondary & & & 0.92 & & & & & 0.93 & \\
\hline Tertiary & & & 1.46 & & & & & 1.22 & \\
\hline Missing & & & 0.83 & & & & & & \\
\hline \multicolumn{10}{|l|}{ Age in years } \\
\hline$<20$ & 0.000 & 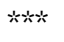 & 0.000 & wht & & 0.001 & $* *$ & 0.001 & $* * * x$ \\
\hline $20-25$ & 0.004 & $* x$ & 0.004 & 知策 & & 0.007 & $* * *$ & 0.005 & 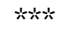 \\
\hline $25-30$ & 0.009 & $* x$ & 0.007 & 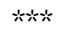 & & 0.013 & $* * *$ & 0.010 & $* * * x$ \\
\hline $30+$ & 0.006 & 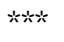 & 0.004 & wht & & 0.005 & $* *$ & 0.003 & $* * * x$ \\
\hline Log likelihood & -212.8 & & -185.2 & & & -275.5 & & -219.5 & \\
\hline
\end{tabular}

$*=5 \% ; * *=1 \% ; * * *=0.1 \%$.

Notes: Education variables each contain a small number of missing values without significant impact (not displayed here).

Education of respondent is a time-varying covariate.

Source: TIES survey 2007-2008 
Table 7.13 Factors influencing marriage versus unmarried cohabitation, by group (odds ratios)

\begin{tabular}{|c|c|c|c|c|c|c|c|c|c|}
\hline \multirow[b]{2}{*}{ Variable } & \multicolumn{4}{|c|}{$\begin{array}{l}\text { Moroccan second } \\
\text { generation }\end{array}$} & \multicolumn{5}{|c|}{$\begin{array}{l}\text { Former Yugoslavian } \\
\text { second generation }\end{array}$} \\
\hline & \multicolumn{2}{|c|}{ Model 1} & \multicolumn{2}{|c|}{ Model 2} & \multirow[t]{2}{*}{ Variable } & \multicolumn{2}{|c|}{ Model 1} & \multicolumn{2}{|c|}{ Model 2} \\
\hline Men & 1 & & 1 & & & 1 & & 1 & \\
\hline Women & 2.9 & $*$ & 3.22 & $* x$ & & 1.53 & $*$ & 1.52 & [0.054] \\
\hline The Netherlands & 1 & & 1 & & Germany & 1 & & 1 & \\
\hline Belgium & 2.89 & $* *$ & 2.34 & $*$ & Austria & 0.93 & & 0.74 & \\
\hline \multicolumn{10}{|l|}{ Birth cohort } \\
\hline 1971-1980 & 1 & & 1 & & & 1 & & 1 & \\
\hline 1981-1990 & 0.57 & {$[0.067]$} & 0.60 & {$[0.069]$} & & 0.29 & $* *$ & 0.27 & $* * *$ \\
\hline \multicolumn{10}{|l|}{ Education } \\
\hline $\begin{array}{l}\text { Primary/special } \\
\text { education }\end{array}$ & 0.66 & & 0.8 & & & 0.39 & & 0.5 & \\
\hline Lower secondary & 1 & & 1 & & & 1 & & 1 & \\
\hline Apprenticeship & 1.21 & & 1.34 & & & 1.51 & & 1.67 & \\
\hline $\begin{array}{l}\text { Upper secondary/ } \\
\text { apprenticeship }\end{array}$ & 1.26 & & 1.55 & & & 1.51 & & 1.8 & \\
\hline Tertiary & 1.21 & & 1.25 & & & 0.32 & $* *$ & 0.33 & $* *$ \\
\hline \multicolumn{10}{|l|}{$\begin{array}{l}\text { Religion during } \\
\text { childhood }\end{array}$} \\
\hline Muslim & & & 2.55 & $*$ & & & & 4.89 & $* *$ \\
\hline Christian & & & - & & & & & 0.87 & \\
\hline None or other & & & 1 & & & & & 1 & \\
\hline \multicolumn{10}{|l|}{ Number of siblings } \\
\hline 0 & & & 1 & & & & & 1 & \\
\hline 1 or 2 & & & 4.02 & & & & & 1.81 & {$[0.077]$} \\
\hline $3+$ & & & 8.03 & & & & & 2.01 & {$[0.065]$} \\
\hline \multicolumn{10}{|l|}{ Father's education } \\
\hline Primary or less & & & 1 & & & & & 1 & \\
\hline Secondary & & & 0.36 & $*$ & & & & 0.63 & \\
\hline Tertiary & & & 1.33 & & & & & 1.29 & \\
\hline Log likelihood & -157.0 & & -131.0 & & -271.8 & & & -260.5 & \\
\hline
\end{tabular}

$*=5 \% ; * *=1 \% ; * * *=0.1 \%$.

Notes: Education variables each contain a small number of missing values without significant impact (not displayed here).

Source: TIES survey 2007-2008 